Pamiętnik Literacki 2017, 1, s. 89-133
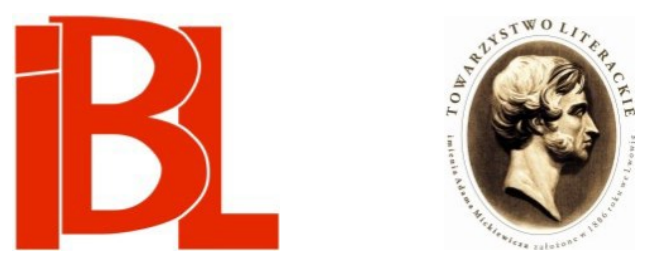

\title{
Dzienniki Emilii z Beniowskich
}

\section{Wróblewskiej}

\author{
Reda Griškaitè
}




\section{2. $\begin{array}{llllllllllllllllll} & \mathrm{M} & \mathrm{A} & \mathrm{T} & \mathrm{E} & \mathrm{R} & \mathrm{I} & \mathrm{A} & \mathrm{E} & \mathrm{Y} & \mathrm{I} & \mathrm{N} & \mathrm{O} & \mathrm{T} & \mathrm{A} & \mathrm{T} & \mathrm{K} & \mathrm{I}\end{array}$}

Pamiętnik Literacki CVIII, 2017, z. 1, PL ISSN 0031-0514

REDA GRIŠKAITÉ Lietuvos istorijos institutas, Vilnius

\section{DZIENNIKI EMILII Z BENIOWSKICH WRÓBLEWSKIEJ*}

Emilia z Beniowskich Wróblewska (5? X 1830 - 23 XII 1886) jest znana przede wszystkim jako matka słynnego wileńskiego adwokata i działacza społecznego, Tadeusza Stanisława Wróblewskiego (1858-1925) ${ }^{1}$. Jej postać - obok postaci męża, Eustachego Wróblewskiego - uwieczniono w nazwie Biblioteki im. Eustachego i Emilii Wróblewskich, założonej w 1912 r. w Wilnie (obecnie - Biblioteka Wróblewskich Litewskiej Akademii Nauk; dalej: BWLAN). Dlatego też Wróblewską zazwyczaj wymienia się tylko w publikacjach poświęconych Bibliotece albo w biogramach czy biografiach dotyczacych jej syna Tadeusza Stanisława, a w ostatnich latach także i drugiego z jej synów - Augustyna Anicetego Wróblewskiego (1866 po 1913$)^{2}$. Rzadziej zaś występuje jako córka ${ }^{3}$ uczestnika powstania listopadowego, Bartłomieja Beniowskiego (ok. 1800-1867). Niekiedy też pisze się o jej związkach

* Pełna wersja artykułu ukazała się w języku litewskim: Emilijos Beniovskytès-Vrublevskienès (Emilia z Beniowskich Wróblewska, 1830-10-05 - 1886-12-23) dienoraščiai (1850-08-05 - 188609). „Archivum Lithuanicum” t. 14 (2012), s. 227-308. W oryginalnej wersji, dostępnej również w Internecie na stronie: http://www.lki.lt/LKI_LT/index.php?option=com_content\&view=article\&id=797\&Itemid=35 (dostęp: 2 IX 2012), znajduje się 18 ilustracji. Cytaty w tekście pochodzące $z$ rękopisów zostały tam przytoczone - zgodnie $z$ wymogami redakcji - bez modernizowania pisowni. W polskim tłumaczeniu pisownię zmodernizowano w myśl zasad współczesnej polszczyzny, przede wszystkim w zakresie ortografii i interpunkcji. [Przypis tłum.].

$1 \quad$ W artykule używam obu imion Tadeusza Stanisława Wróblewskiego. Po zapoznaniu się z rękopiśmienną spuścizną cenionego adwokata i kolekcjonera można wnioskować, że zawsze pierwszeństwo dawał on zapisowi obu imion, tj. Tadeusz Stanisław, a nie tylko: Tadeusz.

2 Zob. H. Ro m [e r - O c h e n k ow s k a], Śp. Tadeusz-Stanisław Wróblewski. „Kurier Wileński” 1925, nr 152. - H. D [r è g e], Śp. Tadeusz Wróblewskijako założyciel biblioteki im. E. i E. Wróblewskich. Wilno 1926. - S. Ryg i e 1, H. D rè ge, Biblioteka im. Wróblewskich w Wilnie (1912-1931). Wilno 1934. - V. Abramavičius, Tadas Vrublevskis. Vilnius 1960. - Z. Ponarski, Adwokat Tadeusz Stanisław Wróblewski (1858-1925). W zb.: Szkice z dziejów adwokatury polskiej. Red. R. Ły czywek. T. 1. Warszawa 1976. - D. Stali ū n a s, Tado Vrublevskio politinés minties bruožai. „Lietuvių Atgimimo istorijos studijos” t. 13 (1996). - D. La b a na u s ki e nè, Tado Vrublevskio jaunystès metai: laiškai iš tremties. „Tarp knygü” 1996, nr 3. - B. Bi ałokozowi cz, Tadeusz Stanisław Wróblewski - założyciel Biblioteki im. Emilii i Eustachego Wróblewskich, patriota Wilna i obrońca praw człowieka. W zb.: Wilno i świat. Dzieje środowiska intelektualnego. Red. E. Feliksiak, M. Leś. T. 1. Białystok 2002. - R. Anto nów, wstęp w: A. W róblewski, Anarchista z rozpaczy. Wybór pism. Wybór, wstęp, przypisy R. An to nów. Kraków 2011, s. VII n.

3 Właśnie córka, bynajmniej nie wnuczka, jak twierdzi P on arski (op. cit., s. 55). 
z Walerym Antonim Wróblewskim (1836-1908) ${ }^{4}$, jednym z przywódców powstania styczniowego, później generałem Komuny Paryskiej, a prywatnie bratankiem i wychowankiem jej męża, Eustachego Edwarda Wróblewskiego (1826-1891). Wróblewska zatem najczęściej wspominana jest w kontekście biblioteki noszącej jej imię oraz na tle znanych mężczyzn $z$ jej rodziny. Znacznie rzadziej akcentuje się jej pedagogiczna działalność. Nie tylko nazywana jest doskonała nauczycielką („nauczycielka z zawodu i zamiłowania”) ${ }^{5}$, mówi się również, że była właścicielka tajnej pensji dla dziewcząt, funkcjonującej przez 40 lat w Wilnie. Po raz pierwszy w prasie pisała o tym w 1925 r. Helena Romer-Ochenkowska (1875-1950), a w 1932 r. Ludwika Życka (1859 - po 1939), która od 1902 r. sama prowadziła tajne nauczanie w Wilnie ${ }^{6}$. Szerzej o nielegalnej działalności pensji Wróblewskiej wspominał też kolekcjoner, publicysta i historyk Lucjan Uziębło (1864-1942)7, który wymienił bardziej znanych uczniów diarystki. Badacz podkreślał, że w tej konspiracyjnej szkole edukację początkową odbywały dziewczęta $z$ najznamienitszych rodzin $z$ Wilna i Wileńszczyzny. Tę samą informację już na początku naszego stulecia powtórzyli prawie dosłownie historyk literatury Andrzej Romanowski, a także znany slawista Bazyli Białokozowicz ${ }^{8}$. Wróblewską jako właścicielkę tajnej pensji dla dziewcząt przedstawiono również w najnowszej książce poświęconej Wróblewskim - we wspomnianym tu zbiorze pism Augustyna Wróblewskiego ${ }^{9}$.

Żaden $z$ tych badaczy, oprócz Uziębły, nie poparł swoich stwierdzeń odniesieniami do konkretnych źródeł, dlatego też można się domyślać, że zasugerowali się oni przede wszystkim epitafium znajdujacym się na grobie Wróblewskiej na cmentarzu Na Rossie: „Czterdzieści lat dzieci uczyła”10. Z drugiej strony, przekaz o jej tajnej działalności pedagogicznej istniał w tradycji rodzinnej, a to już znaczacy argument. Mam na myśli wspomnienia Jadwigi z Sikorów Wróblewskiej (1889-1956), żony Augustyna Wróblewskiego, ogłoszone w Londynie w 1960 roku ${ }^{11}$. Autobiograficzna spuścizna Emilii Wróblewskiej, zwłaszcza jej dzienniki, nie zaświadcza jednak o żadnej dodatkowej działalności pedagogicznej po r. 1857, tj. od jej ślubu z Eustachym Wróblewskim. Dzienniki w oczywisty sposób ujawniają, że wszystkie pedagogiczne wiadomości i doświadczenia wykorzystywała ona jedynie w pracy $z$ własnymi dziećmi. O tajnym nauczaniu diarystka mogła wszakże nie wspominać ze względów bezpieczeństwa. Całkowicie należy odrzucić jedynie opinię Vladasa Abramavičiusa,

4 Zob. W. E. Abramawiczius [V. Abramavičius], W. A. Djakow, Walerij Wrublewskij. Moskwa 1968, s. 105. - J. V. B or ei ša, Patriotas be paso. Vilnius 1973, s. 104.

5

6 Rom [e r-O c h en kow s ka], op. cit., s. 2. - L. Ży c ka, Krótki rys dziejów tajnej oświaty polskiej na ziemi wileńskiej od 1880 do 1919. Wilno 1932, s. 4.

7 Ów c zes ny [L. U z i ę bło], Wróblewscy - ich prace i stosunki wileńskie. „Słowo” 1935, nr 180, s. 6.

8 A. Rom a now s ki: Polska oświata i nauka w Wilnie doby pozytywizmu. W zb.: Wilno i świat, t. 1 , s. 156; Pozytywizm na Litwie. Polskie życie kulturalne na ziemiach litewsko-białorusko-inflanckich w latach 1864-1904. Kraków 2003, s. 285. - Bi ał o k o z o w i c z, op. cit., s. 206.

9 Antonów, op. cit., s. VII.

10 A bram a viči u s, op. cit., s. 5: „Moké vaikus ištisus keturiasdešimt metu”. [Wszystkie przekłady przytoczonych tu fragmentów z tekstów litewskich pochodzą od tłumaczki; polską wersję umieszczono w tekście głównym, a litewski oryginał - w przypisie. Przypis tłum.].

11 J. Wróblew ska, Listy z Polski. Do druku przygot. M. Wróblew s ki. Wstęp W. Wo h nout. London 1960, s. 26. 
który twierdził, że matka Tadeusza Stanisława Wróblewskiego „należała do nielicznego kręgu kobiet, które odebrały wykształcenie za granica”" 12 .

Większość przywołanych tu badaczy poświęciła postaci Wróblewskiej zaledwie kilka słów. Nawet w opracowaniach na temat cmentarza Na Rossie ograniczono się do biogramów męża i syna diarystki ${ }^{13}$. Dotychczas nieco więcej uwagi zwrócili na Wróblewską, a właściwie na jej autobiograficzną spuściznę, literaturoznawczyni i bibliotekarka Danutė Petkevičiūtè-Labanauskienė, historyk Darius Staliūnas oraz wspomniany literaturoznawca Białokozowicz ${ }^{14}$. Badacze ci, których przede wszystkim interesował Tadeusz Stanisław Wróblewski, nie omówili osobno biografii jego matki, ale korzystali z jej dziennika pisanego dla syna, jak też z obszernej korespondencji, dzięki czemu - choć niebezpośrednio - udało im się naszkicować portret Wróblewskiej. W kontekście uwięzienia i wygnania Tadeusza Stanisława nieco wcześniej wspomniał jego matkę także historyk Boris Klejn ${ }^{15}$. Badacz ten prawdopodobnie znał materiały ze śledztwa w sprawie Wróblewskiego, wśród których znajdowały się również dokumenty dotyczące Emilii Wróblewskiej.

Wróblewska nie pojawia się w zachowanej memuarystyce. Jedyne świadectwo (pomijając krótkie refleksje Uziębły) to wspomnienia Sikory-Wróblewskiej. Obie kobiety nie znały się dobrze, dlatego autorka Listów z Polski w dużej mierze opierała się na opowieściach swego męża ${ }^{16}$. W książce przedstawiła niezbyt przychylną opinię o jego matce: Emilię oskarżano o brak serdeczności, nawet o obłudę. Mimo tych ciemnych kart w biografii synowa nie mogła przemilczeć patriotycznej postawy Wróblewskiej, zwłaszcza podczas powstania styczniowego ${ }^{17}$. Ale to jedyna pozytywna charakterystyka.

Osobnego miejsca nigdy nie poświęcono nie tylko życiorysowi Emilii Wróblewskiej, lecz także jej spuściźnie rękopiśmiennej, której dużą część stanowią dzienniki. Stało się tak z kilku powodów. Po pierwsze, dzienniki diarystka pisała po polsku, przez co automatycznie wyeliminowano je $z$ litewskiej kultury. Przykładem tradycyjnego myślenia o prowadzeniu dzienników jest studium Rimantasa Glinskisa, w którym autor stwierdza, że - w odróżnieniu od reszty Europy w XIX w. - na Litwie w ogóle nie rozwinęły się one jako gatunek (!) ${ }^{18}$. Niektórzy badacze reprezentują jednak zupełnie inne stanowisko - np. historyczka Tamara Bairašauskaitė podaje kilka przykładów XIX-wiecznych dzienników pozostających w rękopisach, w tym także tworzonych przez kobiety ${ }^{19}$. Należy żałować, że badaczka, omawiając obszer-

A b r a m a vi či i s, op. cit., s. 5: „Priklausé negausiam pedagoginį moksla užsienyje išèjusių moteru būreliui".

Zob. E. Mała chowicz, Wilno. Dzieje, architektura, cmentarze. Wrocław 1996, s. 428, 481 n. - V. Girininkienè, A. Paula uskas, Rasos. Vilnius 1998, s. 74-75, nry 175, 176.

Labanauskienè, op. cit., s. 35-36. - Staliūnas, op. cit., s. 152-154. - Białokozowicz, op. cit., s. 207-208.

B. S. Kle j n, Wzglad iz proszłogo. Istoriko-dokumientalnyje oczerki. Minsk 1989, s. 122.

Najprawdopodobniej z tego powodu, a także ze względu na to, że pamiętniki zwykle pisane sa już pod koniec życia, wspomnienia te są niedokładne. Np. Bartłomiej Beniowski jest nazywany bratem Emilii Wróblewskiej. Zob. Wr óblew s ka, op. cit., s. 27.

Ibidem.

R. G li n s k is, XX amžiaus lietuviu dienoraščiai: tarp literatūros ir dokumento. Vilnius 2006, s. 11. T. B a ir a š a u ska i tè, Dzienniki szlachty litewskiej z XIX wieku $w$ zbiorach wileńskich. „Białostocczyzna" 1999, nr 2. 
niej trzy szlacheckie teksty autobiograficzne $z$ tamtego czasu - pomiędzy nimi słynny dziennik Pauliny z Monwid-Białłozorów Kończyny (1821-1881), żony Medarda Kończy (1808-1899), powstańca, konspiratora i wygnańca - interesująca nas twórczość Emilii Wróblewskiej przedstawiła fragmentarycznie ${ }^{20}$. $Z$ drugiej strony, XIX-wieczną litewską diarystykę kobiecą dotychczas analizowano i publikowano bardzo rzadko. W tym kontekście szczególnie ważny jest pisany po niemiecku dziennik Gabrieli Eleonory z Mohlów Basanavičienè (1861-1889), żony Jonasa Basanavičiusa (pol. Jan Basanowicz, 1851-1927), litewskiego działacza narodowego, wydany przed 5 laty, po raz pierwszy in corpore, przez literaturoznawcę Vaidasa Šeferisa ${ }^{21}$. Edytora nie zniechęcił ani językowy aspekt dziennika, ani to, że tekst ten był dla diarystki „przede wszystkim przestrzenią uczuć i marzeń, w której momenty codzienności pojawiały się tylko fragmentarycznie, mimowolnie"22. Uznanie tzw. uczuciowości za cechę kobiecej diarystyki skutkowało przez wiele dziesięcioleci przekonaniem, że dziennik to źródło drugorzędne, nie do końca poważne, co tłumaczy, dlaczego świadomie pomijano tego rodzaju dokumenty; jest to również druga przyczyna niepopularności diariusza Emilii Wróblewskiej.

Niektórzy badacze przyznają, że dla historyka dziennik stanowi szczególną wartość, jeśli jego autorem jest osoba związana $z$ kulturą albo odgrywająca w historii ważną rolę ${ }^{23}$. Inni twierdzą odwrotnie - że po wprowadzeniu do obiegu naukowego rękopiśmiennych tekstów $\mathrm{z}$ zakresu intymistyki ich autorzy zostaja jak gdyby „uhistorycznieni” ${ }^{24}$. Dzienników Emilii Wróblewskiej nie możemy łatwo przyporządkować ani do pierwszej, ani do drugiej kategorii. Nie nazwalibyśmy matki dwóch słynnych synów nieznaną, jednak nie zaliczylibyśmy jej też do sławnych twórców czy znaczących osobistości - nie tylko dlatego, że do końca nie potwierdzono jeszcze (lecz i nie zanegowano) jej udziału w tajnym nauczaniu, ale również dlatego, że nie wydano dotychczas ani jednego jej tekstu. To kolejny - trzeci już i pewnie najważniejszy powód „niedostrzegania” Wróblewskiej. Brak edycji dzienników mógł być spowodowany przyczyną natury psychologicznej - obawą, że nikt nie zechce czytać dzieła o tak dużej objętości (1181 stronic, 588 kart); dodatkowych problemów nastręcza badaczom często niezbyt czytelny charakter pisma.

Mimo to nazwisko Wróblewskich pomału wraca do naszego historiograficznego dyskursu - nie tylko zresztą za sprawą Tadeusza Stanisława Wróblewskiego. Pierwszym krokiem w kierunku popularyzacji rękopiśmiennej spuścizny Emilii Wróblewskiej było umieszczenie informacji o dwóch jej dziennikach w Bazie Litewskiego Dziedzictwa Egodokumentalnego (lit. Lietuvos egodokumentinis paveldas; dalej: LEGODOK) ${ }^{25}$. W spisie tym na razie znajduje się 79 dzienników, w tym 13 prowadzonych przez kobiety. Wiek XIX, który traktujemy jako epokę (1795-1915)

Ibidem, s. 36-37.

Mano tèvyne - priejo širdies. Gabrielos Eleonoros Mol-Basanavičienès dienoraštis ir laiškai. Parengè ir vertè V. Šeferis. Vilnius 2009.

Š e f e r i s, ed. cit., s. 28-29: „Visu pirma jausmu ir svajoniu erdve, kurioje kasdienybès fragmentai pasirodo tik probègšmais, netyčia".

Zob. Glinskis, op. cit., s. 16.

Zob. R. Rog er s, Schools, Discipline and Community: Diary-writing and Schoolgirl Culture in Late Nineteenth-century France. „Women's History Review” 1995, nr 1, s. 544.

Zob. „Irašai”. LEGODOK. Na stronie: http://legodoc.lt (dostęp: 2 IX 2015). 
w litewskiej historii, reprezentuje tylko pięć kobiecych diariuszy (dwa opublikowane i trzy pozostające w rękopisach) w językach polskim i niemieckim. Dla porównania można dodać, że pod koniec XX stulecia odnotowano $115 \mathrm{XIX}$-wiecznych dzienników pisanych przez kobiety we Francji ${ }^{26}$. Przed kilkoma laty rosyjscy badacze przeanalizowali 80 rękopiśmiennych i wydanych dzienników od 1780 r. do poczatku lat pięćdziesiątych XIX wieku. $53 \mathrm{z}$ nich napisały kobiety ${ }^{27}$.

XIX-wieczne dzienniki kobiet znajdujące się w bazie LEGODOK nie odzwierciedlaja prawdziwego obrazu kobiecej diarystyki tego okresu, bez względu na to, czy zostały wydane, czy też przechowywane są nadal w formie rękopiśmiennej w litewskich archiwach. Z satysfakcją pragnę stwierdzić, że aż dwa ze wspomnianych pięciu świadectw egodokumentalnych wyszły spod pióra Emilii Wróblewskiej, należy jednak zaznaczyć, że znanych jest aż siedem diariuszowych zeszytów (książek) tej autorki, powstałych w latach 1850-1884. Petkevičiūtè-Labanauskienė, opisując spuściznę epistolograficzną Wróblewskich, którą tworzy aż 799 listów, nazwała ją "wyjątkowo obszerną" 28 . To samo można powiedzieć o dziennikach Wróblewskiej, które - jak należało się spodziewać - przechowywane są w bibliotece nazwanej imieniem diarystki i jej męża. Celem tego artykułu jest charakterystyka biografii Wróblewskiej i analiza jej rękopiśmiennej spuścizny.

\section{Szkic biograficzny}

Biografię Emilii Wróblewskiej można odtworzyć przynajmniej częściowo na podstawie oficjalnych dokumentów (świadectwa urodzenia, dyplomu ukończenia szkoły, tablic genealogicznych itp.), a także spuścizny diarystycznej, epistolograficznej oraz literackiej. Wszystkie te rękopisy i dokumenty przechowywane są w zespołach archiwalnych (fondach) BWLAN - F 9 („Bendrasis fondas”, tj. „Zbiór ogólny”) i F 75 (,Mokslu bibliotekos archyvas”, tj. „Archiwum Biblioteki Akademii Nauk”). Zespoły te należą do najstarszych $\mathrm{w}$ bibliotece; $\mathrm{w}$ ich skompletowaniu bezpośrednio uczestniczył Tadeusz Stanisław Wróblewski. Nie dziwi zatem, że ważne miejsce zajmuje w nich spuścizna rodzin Beniowskich i Wróblewskich.

Najcenniejszym dokumentem związanym $z$ Emilią Wróblewską jest kopia wypisu z 13 III $1842^{29}$ (datowana na 2 VII $1855^{30}$ ) z ksiag konsystorskich biskupstwa

Zob. Ph. Lej e un e, Le Moi des demoiselles. Enguête sur le journal de jeune fille. Paris 1993, s. 295-341.

Zob. I. S a wkin a, Razgowory s zierkałom i zazierkaljem. Awtodokumientalnyje żenskije tieksty $w$ russkoj litieraturie pierwoj połowiny XIX wieka. Moskwa 2007, s. 97.

D. La b a n a u s ki e nè, Tado Vrubleuskio rankraščiu kolekcijos. „Lietuvos mokslu akademijos biblioteka” 2001-2002, s. 14: „Ispūdingai gausiu”.

W tym miejscu i następnych daty będą zapisywane w takiej postaci, jak w źródłach. Od roku 1800 na większości ziem dawnego Wielkiego Księstwa Litewskiego obowiązywał kalendarz juliański. Jednak zdarzało się wiele pomyłek, ponieważ niektórzy mieszkańcy tego obszaru tradycyjnie zapisywali daty według kalendarza gregoriańskiego, a inni według juliańskiego. Nierzadko jedna osoba zapisywała daty na dwa sposoby. Dlatego też, chcąc ustalić każdą datę, często trzeba przeprowadzić specjalne badania. W dziennikach Emilii Wróblewskiej daty zwykle zapisywane są według kalendarza juliańskiego.

Zob. wypis $z$ ksiag konsystorskich biskupstwa rzymskokatolickiego w Wilnie, wskazujący date urodzenia, miejsce i chrzest Emilii Beniowskiej. 13 III 1842. BWLAN. Rkps 75-108, k. 8r-9v. 
rzymskokatolickiego w Wilnie. W dokumencie odnotowano, że Wróblewska urodziła się w październiku 1830 w guberni grodzieńskiej, w mieście Kobryń, w rodzinie majora Bartłomieja Beniowskiego, lekarza w białostockim pułku piechoty Armii Rosyjskiej, oraz Augustyny z Kryńskich Beniowskiej (1809-1869). Kobryń, jedno z najstarszych miast Wielkiego Księstwa Litewskiego, nie był szczególnie ważnym miejscem dla rodziny Kryńskich i Beniowskich - w tym czasie stacjonował tam pułk Beniowskiego. Emilię, pierwsze i jedyne dziecko Bartłomieja i Augustyny, ochrzczono (o tym także zaświadcza dokument) nie w kościele, ale tam, gdzie się urodziła - w mieszkaniu wynajmowanym od Marcina Rudominy z Kobrynia. Nie odnotowano imion rodziców chrzestnych, wiadomo tylko, że chrztu udzielił Walenty Kulesza. Narodzin dziewczynki nie zarejestrowano ani w metrykach kościoła katolickiego w Kobryniu, ani w księgach kapelańskich białostockiego pułku - najpewniej z tego powodu tak późno zwrócono się do konsystorza ${ }^{31}$.

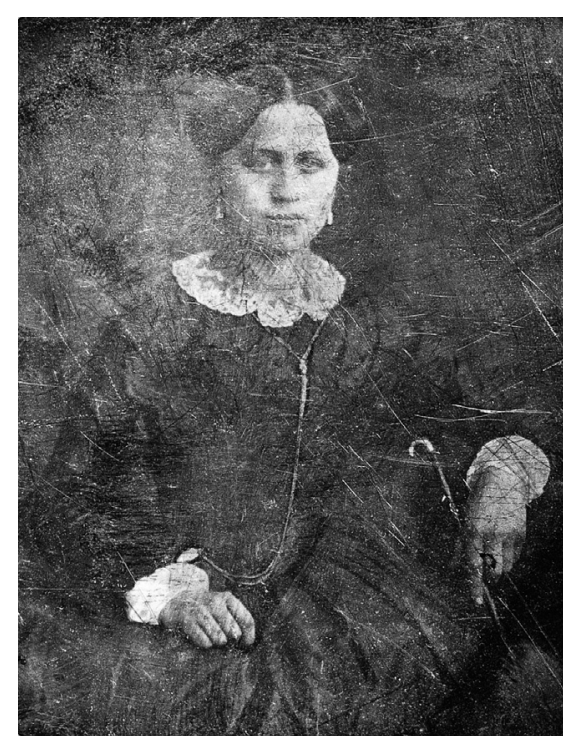

Emilia z Beniowskich Wróblewska (1830-1886)

Dagerotyp nieznanego autora, Wilno 1856; Litewskie Muzeum Narodowe

Opublikowany w: Dagerotipai, ambrotipai, ferotipai Lietuvos muziejuose. Wilno 2000

W tym miejscu warto wspomnieć „pikantny” szczegół z historii: rodzina Beniowskich wywodziła swoje pochodzenie od słynnego konfederata barskiego, króla Madagaskaru i uczestnika wojny o niepodległość Stanów Zjednoczonych, pamiętnikarza Maurycego Augusta Beniowskiego. Ta niezwykła postać (po 1758 r. Beniowski rzeczywiście przez pewien czas mieszkał na Litwie ${ }^{32}$ ) jest równie ważna nie tylko dla Litwinów i Polaków, Słowaków i Węgrów, lecz także dla Amerykanów i Madagaskarczyków. Poza tym w historiografii Maurycy Beniowski niekiedy występuje jako pra-

31 Zob. ibidem, k. 8r.

32 Zob. K. W. W [ó y c i c ki], Beniowski (Maurycy). W: Encyklopedia powszechna Orgelbranda. T. 3: B-Bol. Warszawa 1860, s. 165. 
dziadek Bartłomieja Beniowskiego ${ }^{33}$. Klejn całkiem odważnie zaliczył Emilię Wróblewską do potomków Maurycego: „Istnieją dowody na to, że była potomkinią słynnego konfederata, Maurycego Beniowskiego, człowieka, który stał się legendą"34.

Chociaż dotychczas nie potwierdzono pokrewieństwa Maurycego i Bartłomieja Beniowskich, a biografowie Maurycego Beniowskiego nie podkreślają tego faktu ${ }^{35}$, to legenda taka w rodzinie istniała ${ }^{36}$. Podsycać ją mógł ciagły rozgłos towarzyszaccy Maurycemu Beniowskiemu - powstawały o nim opery, powieści i dramaty (jeszcze zanim Juliusz Słowacki napisał słynny poemat dygresyjny, który ukazał się w r. 1841 w Lipsku). Duża popularność zyskała tragikomedia Augusta Friedricha Ferdinanda von Kotzebuego, wydana w 1795 r. w Lipsku, Graf Benjowsky oder die Verschwörung auf Kamtschatka. W sztuce von Kotzebuego ideałem kobiety Beniowskiego była jego żona Emilia (w rzeczywistości Anna Zuzanna). Tragikomedię tę znano na całym świecie, często wystawiano ją na scenie ${ }^{37}$. Była słynna zarówno w Polsce, jak i na Litwie (zreszta jak cała twórczość von Kotzebuego), w r. 1807 przetłumaczono ją na język polski ${ }^{38}$. Prawdopodobnie właśnie ta sztuka miała wpływ na wybór imienia dla nowo narodzonej córki Beniowskich.

W świadectwie wydanym $z$ konsystorza odnotowano, że oboje rodzice Emilii wywodzili się ze szlachty (,rodziła się z małżonków ślubnych i szlachetnych”39), chociaż historyk i bibliograf Adam Lewak twierdził, iż Beniowski pochodził z bogatej żydowskiej rodziny z guberni grodzieńskiej ${ }^{40}$. Sama Emilia Wróblewska, która pozostawiła wiele ciekawych informacji na temat swojego ojca, nie omówiła szerzej jego pochodzenia, ale w krótkiej biografii Beniowskiego wskazała, że był on uczniem Imperatorskiego Uniwersytetu Wileńskiego, doktorem nauk medycznych ${ }^{41}$. Józef Bieliński nie wymienił nazwiska Beniowskiego w rejestrze medycznych dysertacji doktorskich obronionych na uniwersytecie, dlatego też informacja ta wymaga potwierdzenia ${ }^{42}$. Księgi rejestracyjne studentów poświadczaja, że Beniowski studiował

Zob. D [rège], op. cit., s. 1. - Staliūnas, op. cit., s. 152. - Białokozowicz, op. cit., s. 207. Klejn, op. cit., s. 118.

Zob. M. Le pe c ki, Maurycy August hr[abia] Beniowski, zdobywca Madagaskaru. Lwów-Warszawa 1938.

Zob. Wróblew s ka, op. cit., s. 26.

Podczas premiery Grafa 29 X 1814 w Baltimore wykonano po raz pierwszy hymn Stanów Zjednoczonych Ameryki.

A. F. F. von Kotzebue, Hrabia Beniowski, czyli Wybicie się na wolność. Przeł. A. Glińs ki. Warszawa 1807.

Wypis z ksiag konsystorskich biskupstwa rzymskokatolickiego w Wilnie, wskazujący datę urodzenia, miejsce i chrzest Emilii Beniowskiej, k. 8r.

A. Lew a k, Beniowski Bartłomiej. W: Polski słownik biograficzny. T. 1. Kraków 1935, s. 429. Zob. też T. E. Models ki, Beniowski Maurycy August. W: jw., s. 429-432.

E. z Beniowskich Wróblewska, przedmowa w tłumaczeniu na język polski książki B. Beni ow s ki e go A Handbook of Phrenotypics for Teachers and Students. Cz. 1: Developement of the Principle of Familiarity (London 1842), zatytułowanym potem przez T. S. Wróblewskiego: Notaty z frenotypiki Bartłomieja Beniowskiego, przekład Emilii z Beniowskich Wróblewskiej. [1886]. BWLAN. Rkps 9-242, k. 2r. Dalej do tłumaczenia tego odsyłam skrótem BF. Egzemplarz książki Beniowskiego, przywieziony przez Wróblewską z Londynu, obecnie przechowywany jest w BWLAN, sygn. 41915.

42 J. Bielińs ki, Doktorowie medycyny promowani $w$ Wilnie. Warszawa 1886. Odbitka z „Pamiętnika Lekarskiego Warszawskiego" (1886). 
medycynę na Uniwersytecie Wileńskim ${ }^{43}$. Wynika $z$ nich, iż wstapił on na uniwersytet w 1817 roku. Na podstawie wspomnianych dokumentów można ustalić, że urodził się w 1800 r. w guberni wołyńskiej, w powiecie żytomierskim, w parafii berdyczowskiej. Ważna jest jeszcze jedna rzecz odnotowana w rejestrze: Beniowski został zapisany jako katolik i student - po przedstawieniu dowodu szlacheckiego pochodzenia. Ale uwagę zwraca fakt, iż ojciec diarystki figuruje tam jako „Syn Symeona”, chociaż zazwyczaj używano formy: „Szymon”. Bartłomiej Beniowski studiował dzięki wsparciu państwa; uczęszczał na wykłady z matematyki i literatury, o czym sam potem wspominał („Po siedmiu latach studiów matematycznych, literackich i medycznych, sfinansowanych przez Uniwersytet Wileński [...]”) ${ }^{44}$. Naukę ukończył w 1823 r. - w przeddzień słynnego procesu studentów, ale nazwiska Beniowskiego nie ma w żadnych spisach stowarzyszenia filaretów ani innych tajnych organizacji.

Na horyzoncie historyków po raz pierwszy ojciec Emilii pojawił się jako uczestnik powstania listopadowego - 25 IV 1831 podczas bitwy pod Kuflewem, ryzykując życiem, przeszedł $\mathrm{z}$ armii rosyjskiej na stronę powstańców ${ }^{45}$. Po klęsce powstania wyemigrował do Paryża, gdzie uczył się w słynnej szkole wojskowej L'École d'état-major ${ }^{46}$. W roku 1833 generał Józef Dwernicki wysłał Beniowskiego razem z innymi oficerami do Egiptu, do sławnego reformatora tego kraju, paszy Muhammada Alego. Celem polskich oraz litewskich emigrantów było zdobycie wsparcia egipskich i syryjskich Żydów dla sprawy odzyskania niepodległości. Wróciwszy z Egiptu, Beniowski wkrótce przeniósł się do Londynu, gdzie mieszkał do śmierci. W Anglii nie porzucił polityki: jako anarchista $z$ natury (zgodnie $z$ opinią jemu współczesnych) nie dogadał się $z$ polskimi i litewskimi działaczami emigracyjnymi, ale zaangażował się w życie polityczne jako sympatyk radykałów. Lewak, na podstawie londyńskiej prasy tego okresu, pisał o uczestnictwie Beniowskiego w ruchu czartystów i o związkach $\mathrm{z}$ irlandzkim politykiem Danielem O'Connellem ${ }^{47}$.

Radykalizm ojca Emilii Wróblewskiej i jego lewicowe poglądy potwierdza również lekarz, podróżnik i literat Teodor Tripplin w Pamiętnikach lekarza Polaka z wypadków za granica doznanych. Autor z nieskrywaną ironią pisze o swoim koledze: „niegdyś sztabslekarz i dobry lekarz”, „ale skrzydłom duszy doktora Benio ciasna

Księga rejestracyjna studentów Cesarskiego Uniwersytetu Wileńskiego. 1819-1820. Bibl. Uniwersytetu Wileńskiego (dalej: BUWil). Dział Rękopisów. Rkps 2 - KC 78, k. 76v, nr 305. - Księga rejestracyjna studentów Cesarskiego Uniwersytetu Wileńskiego. 1820-1821. Jw., rkps 2 - KC 79, k. 123r, nr 536. - Księga rejestracyjna studentów Cesarskiego Uniwersytetu Wileńskiego. 18211822, 1822-1823. Jw., rkps 2 - KC 80, k. 132r, nr 589, k. 234v, nr 290.

[B. B e $\mathrm{n}$ i o w s k i], The Anti-absurd or Phrenotypic Alphabet and Ortography for the English Language Invented by Major Beniowski, the Author of the System of Artificial Memory, Designated a Phrenotyphics. London 1844, s. 81. Fragment egzemplarza tej książki, przechowywany w zbiorach BWLAN (sygn. 1355), został przywieziony do Wilna przez córkę Beniowskiego.

45 Zob. Lew ak, op. cit., s. 429.

46 [B e n i ow s ki], The Anti-absurd, s. 81. Zob. też świadectwo Bartłomieja Beniowskiego dotyczące kursu nauczania odbytego w latach 1832-1833, wydane przez L'École d'état-major, 12 III 1833 (BWLAN. Rkps 75-112, k. 3r) oraz zaświadczenie wydane przez Józefa Dwernickiego, dowódce wojsk litewskich i polskich na emigracji, dotyczące przyznania stopnia majora Bartłomiejowi Beniowskiemu, 23 III 1833 (jw., k. 1r).

47 Lew ak, op. cit., s. 429. 
atmosfera medyczna nie wystarczała na rozpięcie się"48, także o jego zainteresowaniach socjalizmem i o wydawanym w Londynie czasopiśmie „The Friend of Workmen"49. Według Tripplina ogarnęła Beniowskiego jeszcze jedna idea - znalezienie metody mogącej udoskonalić ludzką pamięć, o której mówił, że ,jest spichlerzem umu"50. Beniowski wierzył, iż człowieka można uczynić szczęśliwszym nie przez uleczenie ciała, lecz przez oświecenie umysłu i zmianę myślenia. Na utrzymanie i wydawanie gazety Beniowski zarabiał w sposób także niezwyczajny jak na lekarza - szyjąc buty angielskim arystokratkom. „Doktor Szewc” tak wyjaśniał swoją „konwersję":

Powiadam ci, doktorze T., po raz dziesiąty czy dwunasty, daj mi święty pokój z praktyką lekarską, rozbrat wziąłem wieczny i stanowczy z poziomą medycyną od czasu, jak się przekonałem o większej skuteczności oświaty na szczęście i zdrowie człowieka. Niech wprzód będzie lepszym, wówczas mniej będzie cierpiał, a oświata zrobić go musi lepszym; pamięć jest spichlerzem umu, ja zaś poświęcam się na to, żeby tę pamięć, stosunkowo małym wysileniem, w każdym człowieku wzbudzić, zaostrzyć i wzmocnić. A jak się zmęczę mnemotechnika i dziennikarstwem, wówczas dla odpoczęcia, i żeby z głodu nie umrzeć, szyję trzewiki; Jan Jakób Rousseau przepisywał nuty; szyć trzewiki to rzecz jeszcze mniej mechaniczna, więcej urozmaicona. Tedy proszę mi dać święty pokój, nie jestem już lekarzem, niech sobie nim będą inni po poziomie czołgać się lubiący ${ }^{51}$.

Może stąd wzięły się radykalne poglądy wnuków Beniowskiego - Tadeusza Stanisława i, przede wszystkim, anarchosyndykalisty Augustyna Wróblewskiego, który stał się klasykiem polskiej myśli anarchistycznej? Literacki portret Beniowskiego przedstawiony przez Tripplina można uznać za unikatowy, mimo że nie sympatyzował on z Beniowskim: nazywał go „drażliwym, ruchliwym, przytomnym i niezmiernie wygadanym"52, mało tego - słynącym $z$ ciętego języka. Opisał też wygląd zewnętrzny swojego bohatera. Biografowie Beniowskich i Wróblewskich nie korzystali dotychczas z tych materiałów. Być może, nie zauważyli, że wspomniany przez Tripplina londyński dziwak, dawny lekarz z Wilna, „doktor Benio” to nikt inny jak dziadek Tadeusza Stanisława Wróblewskiego, Bartłomiej Beniowski.

Tripplin mieszkał w Londynie w latach 1836-1837, a wspomnienia swoje spisał po blisko 20 latach. Informacje te należy zatem traktować $\mathrm{z}$ ostrożnością - zresztą tak jak większość tekstów tego literata o niejasnej reputacji. Lecz ów portret Beniowskiego potwierdza inne informacje o ojcu Wróblewskiej i nie stoi z nimi w sprzeczności. Ciekawe, że po raz pierwszy o Beniowskim pisał Tripplin krótko również w książce wspomnieniowej, już nie tak popularnej: Anglia dziś i dziesięć lat temu. Ukazując trudne losy emigrantów w Londynie, Tripplin nie mógł nie wymienić Beniowskiego. Tym razem jednak był znacznie bardziej pobłażliwy, choć przedstawiał go znów w takim samym kontekście - szycia damskich butów:

Pracy dostać trudno było nadzwyczajnie człowiekowi nie posiadającemu jakiegoś szczególnego usposobienia, - protekcji, i rzeczy bardzo ważnej w Londynie - pięknych, wykwintnych sukien. Wielu bardzo zdolnych naukowych ludzi wzięło się do rzemiosła. Znany major Ben... doktor medycyny, sławs. 33.

49 Ibidem, t. 6, s. 6.

50 Ibidem, t. 5, s. 34

51 Ibidem, s. 33-34.

52 Ibidem, s. 33. 
ny profesor mnemotechniki, człowiek dziwnie hojnie przez naturę obdarzony, wziął się do szewstwa i szył damskie trzewiki ${ }^{53}$.

Tripplin zauważył, że ojcu Emilii Wróblewskiej natura nie poskąpiła niezwykłych zdolności.

W swojej rękopiśmiennej spuściźnie jedyna córka Beniowskiego pozostawiła obraz ojca podobny do tego ukazanego przez Tripplina. $Z$ tą tylko różnicą, że to, co Tripplin (i nie tylko on) opisywał $\mathrm{z}$ ironią, Wróblewska traktowała jako największą zasługę. Ojciec był dla niej nie tyle powstańcem i politykiem, a więc bohaterem, ile człowiekiem nauki, budzącym podziw otoczenia zarówno dzięki gruntownej wiedzy na temat wszystkich nauk ścisłych, jak i z powodu znajomości 10 języków obcych (sam Beniowski wymieniał 12, wliczając do nich prawdopodobnie polski i rosyjski ${ }^{54}$ ). Był także obcokrajowcem („Ja - obcokrajowiec - stały mieszkaniec krańców cywilizacji”), który zachęcił Anglików do przeprowadzenia reformy ortografii ${ }^{55}$.

Emilii najbardziej jednak imponowała fenomenalna pamięć ojca: jego tzw. seanse pamięci odbywały się w przepełnionych widzami londyńskich salach. Specjalnie skonstruowana maszyna, która Beniowski nazwał "frenotypiką" (ang. phrenotypics), a jego córka określała mianem „obrazów pamięci”, mogła powtórzyć 22000 artykułów z The Encyclopaedia Britannica - fakty i daty ${ }^{56}$, od początku do końca i od końca do początku. Beniowski swoją metodę i wynalazek prezentował nie tylko w National Gallery of Practical Science, Blending Instruction with Amusement, lecz także w South Kensington Museum w Londynie (obecnie: Science Museum). Mówi się, że w obu przypadkach prezentacje te oklaskiwano i chwalono ${ }^{57}$. Nieprzypadkowo Beniowskiego nazywano w londyńskiej prasie „człowiekiem o cudownej pamięci”:

Takim zdziwieniem to wystąienie mego Ojca przyjęła angielska publiczność, iż znaleźli się ludzie tak oryginalnego pomysłu, iz przychodzili do Ojca oglądać go, czy przez jakie zboczenie natury nie miał z tyłu czaszki drugiej pary oczu. Zrobiłby kolosalny majątek, gdyby zechciał objeżdżać Europę, ogłaszając wszędzie, iż będzie okazywać „cuda pamięci”, ale zbyt był humanitarny, by jak skąpiec ukryć skarby swoje dla siebie, li tylko nie dzieląc się nimi z ogólem. Myślał on sobie, iż kiedyś w kochanej ojczyźnie sam swym współrodakom przyniesie w darze te skarby, owoce długoletnich prac połączonych z walką o byt, o życie. Myślał, że chwila ta niedaleko; widząc jednak, iż nadzieja ta coraz ginie we mgle złudzeń, podzielił się nim z dzicem [!] tej ziemi, która biednego wygnańca przytuliła do łona ${ }^{58}$.

Beniowski szył buty i dawał „lekcje pamięci” (,lessons of memory”), dopóki nie owładnęła nim kolejna idea - udoskonalenia techniki poligraficznej59. Maszyna drukarska była jego ostatnim wynalazkiem; patent nabyli później Anglicy, Francuzi, Belgowie i Hindusi ${ }^{60}$.

[T. Tripplin], Anglia dziś i dziesięć lat temu. Wspomnienia z podróży po Anglii. Warszawa 1851, s. 150.

[B en i ow s ki], The Anti-absurd, s. 82.

Ibidem, s. 81.

BF, k. 2v-3r.

BF, k. $2 \mathrm{v}$.

BF, k. 3r-3v.

BF, k. 4r-4v. Zob. też [B e ni ow s ki], Improvement in Printing, Invented and Patented by Major Beniowski. London 1856.

Zob. BF, k. 4v-5r. Zob. też wpis notarialny: umowa między Emilią z Beniowskich Wróblewską a Helen Harris. 13 VIII 1867. BWLAN. Rkps 75-108, k. 12v. 
Beniowski zmarł 29 III 1867 w swoim domu na Bow Street 8, niedaleko opery Covent Garden. Emilia Wróblewska nazywała ojca człowiekiem „potężnej myśli i niezmordowanej pracy i wytrwałości”"61. Świadectwem jego naukowej działalności są nie tylko wypowiedzi jego córki, lecz także jego własne rękopisy i książki. Wśród ciekawszych niewydanych rękopisów można wymienić notatki topograficzne - szkic planowanych prac ${ }^{62}$ - przewiezione przez Emilię Wróblewską do Wilna po śmierci ojca. Opublikowaną spuściznę Beniowskiego reprezentuja prace $z$ lat 1842-1856 - wszystkie ukazały się w Londynie, nakładem samego Beniowskiego i jego drukarni63.

Po śmierci ojca Emilia przewiozła do Wilna zarówno jego rękopisy, dokumenty osobiste, zdjęcia, karty wizytowe, jak i spuściznę autobiograficzna - dziennik i wspomnienia (sądzić tak można na podstawie diarystycznych notatek samej Wróblewskiej), jednak los pamiętników Beniowskiego jest dziś nieznany.

Wróblewska zabrała ze sobą $z$ Londynu także osobiste przedmioty Beniowskiego związane $\mathrm{z}$ jego działalnością masońską. Jego kontakty z masońskimi lożami w Londynie znane były nie tylko rodzinie. Dyrektor biblioteki Uniwersytetu Stefana Batorego Stefan Rygiel oraz asystentka Tadeusza Stanisława Wróblewskiego i bibliotekarka Helena Drège nazywali Beniowskiego „masonem majorem Bartłomiejem Beniowskim"64. Pamiątki po dziadku znajdowały się w słynnych zbiorach masońskich Tadeusza Stanisława Wróblewskiego ${ }^{65}$. Jedna $z$ nich - wstęga mistrza masońskiego - przechowywana jest dzisiaj w Narodowym Muzeum Litwy (Lietuvos nacionalinis muziejus) ${ }^{66}$. Pierwszą litewską badaczka, zainteresowaną Beniowskim i poszukująca jego śladów w Paryżu była bibliografka i historyczka Marija MašiotaitèUrbšienè (1895-1959) ${ }^{67}$.

Trudno określić, jaką rolę odegrał ojciec w życiu Emilii Wróblewskiej. Beniowski wyemigrował, kiedy jego córka nie miała nawet roku. O tym, że ojciec żyje, dowiedziała się po raz pierwszy w r. 1851, kiedy miała 21 lat. Dowiedziała się, jak pisze, „przypadkiem”68. Jesienią tego roku odnotuje bowiem w swoim dzienniku odwiedziny gościa z Anglii, który przywiózł także wiadomości o ojcu. Chociaż bry-

61 BF, k. 5v.

62 B. B e n i ow s k i, Zapiski topograficzne i inne. BWLAN. Rkps 9-908, k. 1r-17r (w językach polskim i angielskim).

63 Oprócz wspomnianych już prac trzeba wymienić także: [B. Beniowski], The Anti-absurd or Phrenotypic English Prenouncing \& Orthographical Dictionary. London 1845. Książka ta została oprawiona w skórę razem ze słownikiem S. Johnsona - prawdopodobnie jeszcze w Londynie, przez samego Beniowskiego - i trafiła do Wilna tą samą drogą co pozostałe rękopisy (BWLAN, sygn. 18584). Zob. też [B. B e n i o w s k i], Phrenotypic Primer for Blind. London, b. r. - egzemplarz książki przywiozła z Londynu do Wilna Emilia Wróblewska; jest przechowywany w BWLAN (sygn. 55710). Rygiel, Drège, op. cit., s. 1.

65 Zob. Spis zbiorów muzealnych, 20 X 1939 zabranych z Działu Masoników Państwowej Biblioteki im. Eustachego i Emilii Wróblewskich i przewiezionych do Mińska. [Bez daty]. BWLAN. Rkps 75-82, k. 5r, nr 63: „Pieczęć Kryształowa bez oprawy z literami B.B. (należała do Bartłomieja Beniowskiego, dziada Tadeusza Wróblewskiego z linii matki, masona $z$ Londynu). Na pieczęci ręka z mieczem”. Zob. też tę informację w: T. S. Wróblew ski, Spis muzealnych zbiorów masońskich. [Bez daty]. Jw., k. 2lv, nr 63.

66 Zob. Ž. B ū čy s, Masonai Lietuvoje: XVIII a. pabaiga - XIX a. pradžia / Freemasonry in Lithuania: End of 18th - Beginning of 19th Century. Vilnius 2009, s. 20, 141, nr 25.

67 M. U r b š i e n è, Notatnik. 1933. BWLAN. Rkps 163-1060, k. 1r-32r (w językach polskim i litewskim). 
tyjski przybysz nie zrobił wrażenia na Wróblewskiej - wydał jej się tak samo zimny i materialistyczny jak jego kraj („Anglia nie ma serca”) - dała upust emocjom:

O, gdybym podczas tej świetnej wystawy, co cały świat zadziwiła, gdybym wtedy znalazła się w Londynie, oko moje szukałoby nie cudnych wynalazków, nie sztucznych wyrobów, ale w tym tłumie różnych wiekiem i narodem, i stanem ludzi śledziłoby ojca nieznanego. Lecz czyliż by serce nie przeczuło, nie poznało, nie powiedziało „o, to ten!” O, czemuż nie mam pieniędzy, czemu nie mam mocy - iść, odszukać Go, poznać - ojca! Biednego wygnańca! A możeż choć w ostatnich jego chwilach znajdzie córkę - może mnie Bóg jeszcze dozwoli choć schyłek lat Jego osłodzić i otoczyć staraniem i czułością synowską ${ }^{69}$.

Wzmianka o pierwszej wystawie światowej („The Great Exhibition of the Works of Industry of All Nations”, zwanej też „The Great Exhibition” lub „Crystal Palace Exhibition”), która akurat w 1851 r. odbywała się w Londynie, w Hyde Parku, pojawiła się nieprzypadkowo - przypuszczam, iż Wróblewska wiedziała już wtedy o wynalazkach ojca. Prawda jest jednak, że Beniowski nie zdążył pokazać wówczas swojej maszyny drukarskiej - publicznie zaprezentował ją dopiero dwa lata później ${ }^{70}$.

Nie można jednoznacznie stwierdzić, kiedy po raz pierwszy Wróblewska przyjechała do Londynu, żeby zobaczyć się z ojcem - prawdopodobnie między zimą 1855 a latem 1856, tj. przed ślubem, ponieważ jeszcze pod koniec stycznia 1855, przeczytawszy wspomniany szkic Tripplina, pisała:

biada Tobie, Tripplinie - Tyś otworzył me rany. Tyś nie wiedział, że wlewasz boleści Twym piórem w serce od kolebki osieroconej córki. Dobranoc, Ojcze, ja Cię żegnam, kiedym Cię nigdy nie powitała ${ }^{71}$.

Ostatnie zdanie dowodzi, iż przed styczniem 1855 nie widziała się jeszcze $z$ ojcem. Wiadomo tylko, że w spotkaniu uczestniczyła jej matka ${ }^{72}$. W roku 1865 do Londynu pojedzie także Tadeusz Stanisław, żeby zobaczyć się z dziadkiem ${ }^{73}$. W każdym razie od 1851 r. można zauważyć szczególną troskę Wróblewskiej o naukę jezzka angielskiego ${ }^{74}$. Chociaż w połowie XIX w. był on popularny na Litwie, to kobiety, wybierajac go (rzadko), kierowały się modą; traktowano go jako „literacką rozrywkę"75. Języka angielskiego dziewczęta będą uczyć się częściej dopiero w drugiej połowie XIX w., kiedy stanie się on atrybutem arystokracji ${ }^{76}$. W Wilnie jednak także mężczyźni nie mogli pochwalić się znajomością angielskiego - widać to na przykładzie Aleksieja Władimirowa, pierwszego dyrektora Biblioteki Publicznej

(1859-1886) (dalej: DTW). Jw., rkps 9-149, k. 66r (Wilno, 1867; nie wskazano dnia ani miesiąca wpisu).

E. Beniow ska (W róblew s ka), Dziennik 1850-1855 (dalej: D1). Jw., rkps 9-183, k. 37v-38r (Wilno, 16 IX 1851).

The History of Printing. Published under the direction of the Committee of General Literature and Education. Appointed by The Society for Promoting Christian Knowledge. London 1855.

D1, k. 86r-86v (Wilno, 28 I 1855).

Zob. DTW, k. 66r (Wilno, 1867; nie wskazano dnia ani miesiąca wpisu).

Zob. ibidem.

Zob. D1, k. 91r (Połaga, 4 IX 1855).

Zob. T. B a ir a š a u s k a it è, Mykolas Juozapas Römeris (1778-1853): bajoro viešoji ir privatierdvés XIX a. pirmojoje puséje. Vilnius 2011, s. 238.

Zob. A. B oł dy r ew, Matka i dziecko $w$ rodzinie polskiej. Ewolucja modelu życia rodzinnego $w$ latach 1795-1918. Warszawa 2008, s. 208. 
w Wilnie, przybyłego do miasta w r. 1866, który na tle otoczenia wyróżniał się doskonałą angielszczyzną (żona Władimirowa była Angielką).

Znajomość języka angielskiego w przypadku Wróblewskiej rozwijała się: wielu wilnianom i wilniankom będzie ona pomagać w czytaniu listów przysyłanych zza Atlantyku ${ }^{77}$; właśnie $z$ tego języka na polski przetłumaczy książkę ojca - pracę o frenotypice. Angielski będzie doskonalić także podczas trzech wizyt w Londynie. Po raz ostatni - już po śmierci ojca - w stolicy Anglii spędzi trzy miesiące. Tak jak ojciec Wróblewska miała wyjątkowe zdolności językowe. Taka była też tradycja rodzinna, gdyż dziadka ze strony ojca, Symeona Beniowskiego, syn nazywał najznakomitszym lingwista, jakiego kiedykolwiek znał ${ }^{78}$.

Stratę ojca bardzo odczuła: „Jakkolwiek życie moje całe $z$ dala od ojca spędziłam, to przekonanie, że już go nie ma, tak jest bolesnym, że wyrazić tego niepodobna"79. Przez trzy samotne miesiące w Londynie, $z$ dala od Wilna i rodziny, przebywała wśród pamiątek po ojcu, które wprawiły ją w zachwyt nad Beniowskim. Najwięcej jednak dowiedziała się o zmarłym $z$ intymnych zapisków, które pomogły jej spojrzeć w inny sposób także na jej własne życie:

Czyliż czytanie to pamiętników Ojca, wtajemniczenie się w jego duszę ma być dla mnie bez pożytku. Nie - widok tego wielkiego ducha, genialnych jego pomysłów, ta chciwa chęć wiedzy, ta ciagła dążność do doskonałości, ta jego wytrwałość w pracy - podnosi mię, czyni mię dumną, że tak powiem, i wskazuje mi zarazem, jak czas jest drogim, jak chwile, które tracę marnie, ja, córka tego znakomitego człowieka, mogłabym użyć na wydoskonalenie jakiej jednej choćby zdolności, którą musiałam otrzymać po ojcu w dziedzictwie, na wydoskonalenie jej tak, by ona przyniosła korzyść dla mojej rodziny i pożyteczną być mogła dla ogółu. Tak przejmę się głęboko tą prawdą, że życie dane nam jest na pracę, według naszych zdolności i talentów, które przez pracę się kształcą i powiększają; że szkoda jest, wstyd jest nawet na próżne gawędy tracić skarbu tak drogiego ${ }^{80}$.

Ten imponujacy człowiek był szczególnie rzadkim gościem w dziennikach córki, ale tłumaczeniu jego książki A Handbook of Phrenotypics for Teachers and Students poświęciła ona ostatnie miesiące swojego życia. Przedmowa powstała $\mathrm{w}$ Wilnie, $16 \mathrm{XI}$ 1886, tj. nieco ponad miesiąc przed śmiercią diarystki ${ }^{81}$. Istotne jest także, że pracy tej podjęła się Wróblewska na prośbę syna, Augustyna - nie tylko słynnego anarchisty, lecz także uczonego.

Może już się nie zobaczymy, ale choć ciało moje złożą do grobu, ja nie umrę - ja żyć będę w Twoich dzieciach, wnukach i prawnukach i przez nich dokonam, czego mnie samemu dokonać nie było dano!

- tak powiedział córce Beniowski podczas ich ostatniego spotkania ${ }^{82}$.

Więcej miejsca przeznaczyła Wróblewska w dzienniku dla matki, Augustyny

Zob. E. z Beniow ski ch Wróblew s ka, Dziennik 1860-1870 (dalej: D3). BWLAN. Rkps 9-236, k. 113r (Wilno, 11 II 1865).

[B en i o w s k i], The Anti-absurd or Phrenotypic Alphabet and Ortography for the English Language Invented [...], s. 81.

D3, k. 130r (Wilno, kwiecień 1867; nie wskazano dnia wpisu).

E. W ró ble w s k a, Notaty pedagogiczne. [Londyn 1867] (dalej: D4). BWLAN. Rkps 9-311, k. 2r-2v (nie wskazano dnia ani miesiąca wpisu).

BF, k. 6r.

BF, k. 5v. 
z Kryńskich. Wyrażała się o niej bardzo przychylnie - matka była dla niej przykładem poświęcenia i pracowitości. Słowo „Matka” zawsze pisała dużą literą. W roku 1851 przyznała, że przez cały czas cieszyła się nie tylko jej opieką, lecz także przyjaźnią: „Opieka czułej i dobrej Matki nie dała mi zaznać biedy, w Niej miałam przyjaciółkę i opiekunkę"83.

Losy Augustyny (właśc. Augustyny Aleksandry ${ }^{84}$ ) - urodzonej 20 VIII 1809 w Brześciu Litewskim - były nie mniej skomplikowane niż jej męża: przeżyła burzliwy okres powstania i trudne czasy popowstaniowe, była żona politycznego skazańca (dezertera $z$ armii rosyjskiej) i emigranta, szukająca azylu u matki, później u siostry, Leokadii z Kryńskich Andrzejkowiczowej (1810-1882), po śmierci jej męża przebywała w domu siostry babci, w jakimś mieście V., potem znów w domu Andrzejkowiczowej w Wilnie, być może w latach 1836-1837. Z zapisków Emilii i spuścizny autobiograficznej samej Augustyny Beniowskiej możemy wysnuć wniosek, że matka diarystki zdobyła w młodości całkiem solidne wykształcenie: była oczytana, znała języki, grała na instrumentach ${ }^{85}$. Dlatego kiedy pozostała bez wsparcia męża, na chleb zarabiała udzielaniem lekcji - w prywatnych domach i w szkołach dla dziewcząt: u wileńskich sióstr bernardynek, wileńskich wizytek, a wreszcie, w 1843 r. - na pensji na poziomie szkoły początkowej, prowadzonej przez Leokadię Andrzejkowiczową (w $1845 \mathrm{r}$. pensje przekształcono w szkoły dla dziewcząt na poziomie szkół powiatowych) ${ }^{86}$. $Z$ dzienników Emilii Wróblewskiej jasno wynika, że choć pensję zarejestrowano tylko na ciotkę Leokadię, to przez rodzinę była traktowana jako instytucja prowadzona przez obie siostry.

Dziennik Wróblewskiej jest świadectwem idealnej przyjaźni Augustyny i Leokadii. Dowodzi tego także epitafium umieszczone przez siostrzenicę na nagrobku Andrzejkowiczowej na wileńskiej Rossie (obok grobu jej siostry): „Leokadia Andrzejkowiczowa, zm. 12 kwietnia 1882 r. w wieku lat 72. Spoczęła obok siostry, z którą łączyła ją miłość bratnia i wspólna wieloletnia praca dla dobra ogółu. Cześć Jej pamięci”. Wróblewska wciąż podkreślała, że miała dwie matki - obie nazywała: „Matkami”. „Ja nie wiedziałam o niczym, nie brakowało mi niczego, jak gdybym była dzieckiem dostatnich rodziców" - pisała ${ }^{87}$. Rzeczywiście, nigdy nie dane było jej doświadczyć niedostatku.

Wykształcenie zdobywała najpierw w domu, a potem u panny R., przyjaciółki

83 D1, k. 32r (Wilno, 5 X 1851). Korespondencja jeszcze wyraźniej ukazuje wyjątkową relację matki z córką. Zob. A. z Kryńskich Beniowska, list do E. z Beniowskich Wróblewskiej, z 31 XII 1864. BWLAN. Rkps 7-2040, k. 2r-2v.

84 Zob. wypis z metryki urodzin Augustyny z Kryńskich Beniowskiej. 18 IV 1879. Jw., rkps 75-115, k. lr.

85 A. z Kryńskich Beniowska: Duchowy testament. [Bez daty]. Jw., k. 2r-3r; Różne zapiski gospodarcze i intelektualne. [Bez daty]. Jw., rkps 9-982, k. 1r-7v - znajdują się tu najrozmaitsze codzienne zapiski, a wśród nich także wykaz książek zalecanych dla kobiet (Spis dzieł do czytania i nauki dla płci żeńskiej w języku polskim. Jw., k. 3r-7v). Elementem codzienności Augustyny była również książka z przepisami kulinarnymi i poradami domowymi, rozpoczęta jeszcze pod koniec r. 1825, która później uzupełniała też jej córka. Zob. A. z Kryńskich Beniowska, Przepisy gospodarskie $i$ kucharskie. 1825. Jw., rkps 9-266, k. 1-186.

86 E. z Beniowskich Wróblewska, Dziennik [1856-1859] (dalej: D2). Jw., rkps 9-272, k. 2v-3v (wpis wprowadzający; Wilno, 1856).

87 Ibidem, k. 3v (wpis wprowadzający; Wilno, 1856). 
matki i ciotki, która nauczyła Emilię podstaw języka francuskiego ${ }^{88}$. Jak większość ówczesnych szlachcianek język ten opanowała w końcu prawie doskonale. Będzie dobrze posługiwać się także niemieckim, jeszcze lepiej rosyjskim. Wspomniałam już, że w odróżnieniu od rówieśniczek będzie czytać i mówić po angielsku. Po śmierci panny R. podjęła naukę w prawdziwej szkole - na słynnej pensji wileńskich wizytek dla zamożnych dziewcząt. Augustyna Beniowska nie płaciła za czesne córki w tej prestiżowej szkole, ponieważ przez 11 godzin dziennie bezpłatnie uczyła tam muzyki. Za murami klasztoru wizytek Wróblewska spędziła swoje najlepsze lata:

Z żalem i bojaźnią opuściłam mury klasztoru i dopiero gdy się zamknęły za mną drzwi żelazne, zdawało mi się, że mię jako niegodną wypędzono z raju, za którym tęskniłam ciągle i tęsknię dotąd jeszcze ${ }^{89}$.

Nie zerwie kontaktów z wizytkami - aż do zamknięcia klasztoru, na początku każdego nowego roku będzie przebywać wśród zakonnic nawet kilka tygodni na rekolekcjach. Z głębokim smutkiem opisze wypadki z 5 III 1865: przymusowy wyjazd 45 wizytek z Wilna. To jeden z niewielu epizodów historycznych, który umieści w swoim dzienniku ${ }^{90}$.

Po opuszczeniu pensji wizytek podjęła naukę na pensji dla dziewczą prowadzonej przez ciotkę i matkę. W roku 1846 16-letnia Emilia otrzymała świadectwo ukończenia pensji ${ }^{91}$. Świetnie wypadła podczas powszechnego egzaminu końcowego: „Zawsze byłam pierwszą - obsypywano mnie pochwałami” ${ }^{2}$. Po roku w wileńskim Instytucie Szlacheckim zdała jeszcze jeden egzamin i 27 V 1847 białoruski okręg oświaty (wileński przywrócono dopiero w 1850 r.) wstawł jej pozwolenie na prace nauczycielki nauczania początkowego ${ }^{93}$. 31 III 1848 otrzymała jeszcze jedno zaświadczenie, przyznające jej prawo do udzielania prywatnych lekcji francuskiego ${ }^{94}$. Także tym razem jej wiedza okazała się rozległa. Mało tego, w obecności egzaminatorów pomyślnie przeprowadziła próbną lekcję: Traduction et explication de l',Ode de Pompignan sur la mort de Rousseau”. Tradycyjnie pozwolenie na pracę nauczycielki domowej - na podstawie protokołu egzaminacyjnego wydanego przez Instytut Szlachecki - potwierdziła rada Imperatorskiego Uniwersytetu św. Włodzimierza w Kijowie, a podpisał je naczelnik białoruskiego okręgu oświaty, Ewaryst Gruber.

Prawdziwa prace nauczycielska podjęła dopiero w r. 1851 - a więc zanim ukończyła dwudziesty pierwszy rok życia - na wspomnianej pensji, prowadzonej przez matkę i ciotkę. Uważała, że tylko w ten sposób może być pożyteczna dla społeczeństwa:

Ibidem, k. 3v-4r (wpis wprowadzający; Wilno, 1856).

Ibidem, k. 4v (wpis wprowadzajacy; Wilno, 1856).

D3, k. 114r (Wilno, marzec 1865; nie wskazano dnia wpisu).

Świadectwo wydane Emilii Beniowskiej po ukończeniu pensji dla szlachcianek, prowadzonej przez Leokadię z Kryńskich Andrzejkowiczową. 15 VI 1846. BWLAN. Rkps 75-108, k. 1r.

D2, k. 5v (wpis wprowadzający; Wilno, 1856).

Świadectwo wydane Emilii Beniowskiej, zezwalające na pracę nauczycielki nauczania początkowego. 23 V 1847. BWLAN. Rkps 75-108, k. 2r.

Świadectwo wydane Emilii Beniowskiej, zezwalające na udzielanie prywatnych lekcji francuskiego. 31 III 1848. Jw., k. 3r. 
Życie moje całe od dzieciństwa aż do dni dzisiejszych zajęte było i jest uczeniem się samej, a potem wlewaniem tego, co umiem, w dziecinne główki. Piękne moje powołanie, piękna, choć nie kwiecista, rozwija się przede mną przyszłość. Moje prace, moje zajęcia nie siebie samą, bez drugich, mieć ciągle będą na celu. Gdybym tylko godnie umiała spełnić moje posłannictwo ${ }^{95}$.

Od tego momentu całym światem Emilii były uczennice i, oczywiście, książki. W odróżnieniu od rówieśniczek nie lubiła tańczyć i muzykować, rysowała przeciętnie i nie znosiła prac ręcznych. Miała powołanie do pracy pedagogicznej, a może nawet do nauki. Wskazują na to jej rękopisy i świadectwo ukończenia szkoły: z języków, nauk ścisłych i historii - stopnie bardzo dobre („otlicznyje”) i wzorowe („oczeń choroszyje”), z kaligrafii, muzyki i prac ręcznych - tylko dobre („choroszyje”), z tańca - zadowalające („dostatocznyje”) ${ }^{96}$. Nieszczególnie troszczyła się o wygląd - ten brak dbałości nosił wszelkie znamiona abnegacji. Wychowywana przez matkę, ciotkę i zakonnice, a sama jako nauczycielka na pensji dla dziewcząt, słabo znała świat mężczyzn:

O mężczyznach dziwne wyrobiłam sobie pojęcie i choć na mój wiek dużo już przeczytałam książek, w których oni wystawieni sa pod tak uroczymi kolorami, ja miałam ich za dzikie i bez serca istoty ${ }^{97}$.

Mimo to nie wszystkich oceniała $\mathrm{z}$ równą surowością. Takim wyjątkiem był Aleksander Zdanowicz (1805-1868). Uczeń Cesarskiego Uniwersytetu Wileńskiego, nauczyciel historii powszechnej, literatury łacińskiej i polskiej w wileńskim Instytucie Szlacheckim oraz na kilku pensjach dla dziewcząt, autor podręczników do historii, jak też słowników języka francuskiego i polskiego, także gramatyki języka francuskiego, rzeczywisty członek Tymczasowej Komisji Archeologicznej w Wilnie - to wyjątkowa postać w dziejach miasta. Poza tym mieszkaniec Zarzecza - tam żył i został pochowany na Cmentarzu Bernardyńskim. Znaczącą rolę odegrał również w życiu Emilii:

On w mych oczach wyższym był nad innych ludzi, miałam go za wyjątek i jako wyjątek uważałam wszystkich moich nauczycieli, którzy nie byli dla mnie zwyczajnymi ludźmi i męż c zy zn a mi i ${ }^{98}$.

Jakże dziś byłam ucieszoną z rozmowy choć krótkiej z moim nieocenionym p. Zdanowiczem, człowiekiem rzadkim w teraźniejszym świecie. Ja tak go poważam, tak kocham, jak żadnego obcego człowieka - kiedy mi coś mówi, zda mi się, że słyszę nieznany mi głos ojca ${ }^{99}$.

Jak pisał Stanisław Kościałkowski, Zdanowicz traktował edukację dziewcząt jako priorytetową ${ }^{100}$. Autobiograficzna spuścizna Wróblewskiej, którą Zdanowicz uczył historii powszechnej, a później w pełni wspierał jej karierę pedagogiczną, potwierdza tę opinię ${ }^{101}$.

D1, k. 24r (Wilno, 9 III 1851).

Świadectwo wydane Emilii Beniowskiej po ukończeniu pensji dla szlachcianek, prowadzonej przez Leokadię z Kryńskich Andrzejkowiczową, 15 VI 1846, k. 1r.

D2, k. 5r-5v (wpis wprowadzający; Wilno, 1856).

D2, k. 5v (wpis wprowadzający; Wilno, 1856).

D1, k. 10r-10v (Wilno, 5 X 1850).

S. Ko ś c iał k ow s ki, Aleksander Zdanowicz (1805-1868). Zarys biograficzny. Wilno 1918.

W Dziale Rękopisów BWLAN przechowywany jest niedatowany zeszyt E. Wróblewskiej z konspektami lekcji A. Zdanowicza poświęconych literaturze polskiej - zob. BWLAN, rkps 9-903, k. 1r-24v. Wróblewskiej przypisuje się też konspekty $\mathrm{z}$ historii powszechnej, ale porównanie zeszytów jasno 
Eustachego Wróblewskiego wspomina Emilia po raz pierwszy w swoim dzienniku 27 IV 1856: "Dzień szczęścia, dzień błogosławiony" - tak go nazwał mój Eustachy! Sercem i dusza słowa te jego powtarzam"102. Choć lakoniczne, zdanie to kryje wiele emocji - diarystka zanotowała je w dniu zaręczyn. Żadnego więcej szczegółu o tej znajomości, zaledwie jedno zdanie o okresie narzeczeństwa. W księgach kościoła św. Jana znajduje się wpis informujący, że 15 VII 1857 ksiądz Jakub Szylejko połączył węzłem małżeńskim 31-letniego szlachcica, wdowca Eustachego Wróblewskiego z 27-letnią Emilią Beniowską („Dworian [!] Jewstafija Wrublewskago wdowca 31 goda s Jemilieju Bieniowskoju diewiceju 27 let") ${ }^{103}$. Data ślubu we wspomnianym wpisie mogła być niedokładna - w dzienniku Emilia Wróblewska zawsze podawała nie 15, ale 16 lipca ${ }^{104}$. Dla Eustachego Wróblewskiego był to już drugi ślub - pierwsza żona, Augustyna z Witkowskich (? - 1855), zmarła zaledwie kilka lat wcześniej ${ }^{105}$. Można się domyślać - wskazuje na to genealogia sporządzona ręką samego Tadeusza Stanisława Wróblewskiego - że zmarła podczas porodu albo tuż po nim. Na pewno nie przeżył również noworodek: chłopiec o imieniu Kazimierz (dat jego życia w tabeli w ogóle nie uwzględniono) ${ }^{106}$.

W tablicy genealogicznej Tadeusz Stanisław Wróblewski odnotował jeszcze jedną ważna informację - wymienił swoich dziadków ze strony ojca: Tadeusza Ksawerego Wróblewskiego (1792-1827) oraz Mariannę z Szymonowiczów Wróblewską (1805-1844) ${ }^{107}$. Szlachecka rodzina Wróblewskich pochodziła $z$ powiatu nowogródzkiego (o tym zaświadcza niejeden dokument, który dochował się do naszych czasów) ${ }^{108}$. Eustachy Wróblewski urodził się nie w Nowogródku, lecz w Słonimie, najważniejszym miasteczku w sąsiedztwie powiatu nowogródzkiego. Dzięki wpisowi metrykalnemu znamy również dokładną datę urodzenia - 28 III $1826^{109}$.

Nie zachowały się żadne informacje o dzieciństwie Wróblewskiego, ale wiadomo, że 4 VIII 1836 zdał on do gimnazjum w Słucku, które ukończył 20 VI 1846. Uczył się bardzo dobrze, jak wynika ze świadectwa ukończenia szkoły ${ }^{110}$. Po gimnazjum

wykazuje, że wspomniany rękopis nie został sporządzony przez diarystke - zob. jw., rkps 9-151, k. 369 k. 1-369 (nienumerowane karty archiwalne). D2, k. 10v (Wilno, 27 IV 1856).

Wypis z ksiag metrykalnych kościoła św. Jana w Wilnie, informujący o ślubie Eustachego Wróblewskiego i Emilii Beniowskiej. 22 XI 1864. BWLAN. Rkps 75-104, k. 10r.

D2, k. 10v (Wilno, 16 VII 1856), k. 69v (Wilno, 16 VII 1858); D3, k. 36v (Wilno, 16 VII 1860), k. 103r (Wilno, 16 VII 1864).

Genealogia rodziny Tadeusza Stanisława Wróblewskiego. [Bez daty]. BWLAN. Rkps 75-130, k. 43r. Zob. ibidem.

Ibidem.

Pismo zgromadzenia deputatów szlachty z guberni grodzieńskiej do przewodniczącego szlachty nowogródzkiej Konstantego Radziwiłła, w którym potwierdza się szlachectwo Wróblewskich. 28 XI 1832. BWLAN. Rkps 75-104, k. 3r. - Świadectwo szlachectwa wydane Eustachemu Wróblewskiemu przez Mikołaja Wolskiego, przewodniczącego szlachty nowogródzkiej. [Bez daty]. Jw., k. 5r. Świadectwo wydane przez Aleksandra Domeykę, przewodniczącego szlachty guberni wileńskiej, potwierdzające, że od 23 XI 1842 Eustachy Wróblewski znajdował się w spisie szlachty powiatu wileńskiego. 30 VI 1875. Jw., k. 14r-15v i in.

Wypis z metryki urodzenia Eustachego Wróblewskiego. 15 I 1832. Jw., k. 1r-1v.

Świadectwo ukończenia gimnazjum w Słucku, wydane Eustachemu Wróblewskiemu. 8 X 1846. Jw., k. 7r-7v. Zob. też list pochwalny z gimnazjum w Słucku dla Eustachego Wróblewskiego. 14 IX 1839. Jw., k. 4r. O pilności Wróblewskiego w nauce świadczy również jego zachowany zeszyt 
podją studia medyczne na uniwersytecie w Charkowie. Jednak to właśnie tutaj konsekwentna, uporządkowana kariera Wróblewskiego, z góry zaplanowana przez jego ojca, nagle została przerwana. W roku 1849 wraz ze swoimi kolegami został aresztowany w zajeździe za dyskusje na tematy polityczne i upowszechnianie postaw nielojalnych wobec władzy ${ }^{111}$. Ponieważ ukrywał się i nie uczestniczył w procesie, skazano go zaocznie. Pojmano go dopiero w maju 1850 w Nowogródku. Po miesiącu trafił do guberni saratowskiej, gdzie pracował jako urzędnik niskiego szczebla (miał najniższą cywilną rangę - registratora kolegialnego). Do Wilna przybył jesienią 1856. Na początku tylko na 4-miesięczne wakacje, ale udało mu się zdobyć pozwolenie na stały pobyt. W Wilnie pozostawał pod nadzorem policyjnym ${ }^{112}$.

Eustachy Wróblewski zasługuje na osobne opracowanie biograficzne, był bowiem postacią tak samo barwna jak Bartłomiej Beniowski. Wróblewski również zajmował się kilkoma dziedzinami nauki - tak jak wszyscy mężczyźni w rodzinach Beniowskich i Wróblewskich. Pisano o nim nieco więcej niż o jego żonie, gdyż w jego biografii szukano wspólnych źródeł cech charakteru dwóch jego synów - Tadeusza Stanisława i Augustyna - oraz bratanka, Walerego. Z drugiej strony, biografowie dostarczali niewielu faktów o Wróblewskim i nie zawsze były one zgodne z prawdą: pisano np., że studiował nie tylko w Charkowie, lecz także na uniwersytecie w Kijowie, że był członkiem panslawistycznego bractwa Cyryla i Metodego (18451846) ${ }^{113}$. Źródła nie potwierdzaja jednak, by Wróblewski studiował w Kijowie. Trzeba by przeprowadzić odrębne badania poświęcone jego związkom $\mathrm{z}$ bractwem Cyryla i Metodego, gdyż tę tajną organizację zlikwidowano w styczniu 1847, a Wróblewskiego aresztowano i skazano w 1849 roku. Jego nazwiska nie wymieniono również w spisach osób należących do organizacji.

Watpliwości nie budzi jedynie lekarska biografia Wróblewskiego - wszyscy autorzy podkreślają, że w Wilnie znano go jako gorliwego zwolennika leczenia homeopatycznego ${ }^{114}$. Poświadczają to również dzienniki jego żony oraz inne podstawowe źródła, w tym pisma Juliana Moszyńskiego i Benedykta Bilińskiego, słynnych lekarzy, zasłużonych dla kurortu w Birsztanach ${ }^{115}$. W Wilnie otrzymał Wróblewski wsparcie moralne ze strony kolegów: chociaż nie posiadał dyplomu ukończenia szkoły wyższej, pozwolono mu pracować w zawodzie lekarza homeopaty, tj. zajmować się medycyną alternatywną ${ }^{116}$. Wszyscy koledzy podkreślali jego rozległa wiedzę w tej dziedzinie i poświęcenie w leczeniu pacjentów:

szkolny - zob. E. W ró b le w s k i, Wypisy słówek łacińskich z bajek Korneliusza Neposa i Fedra. 1840-1841. Jw., rkps 9-990, k. 1r-25v (w językach łacińskim i rosyjskim).

111 Zob. opinię policji politycznej o Eustachym Wróblewskim. 1856. Jw., rkps 75-104, k. 16r (w języku rosyjskim).

112 Zob. ibidem, k. 16r-17v. Zob. też pismo wyjaśniające władz guberni saratowskiej o Eustachym Wróblewskim. 14 X 1857. Jw., k. 11r-12r.

113 Zob. V. Abramavičiu s, Valerijonas Vrublevskis. Vilnius 1958, s. 14-15. - Girininkienè, Pa ula u skas, op. cit., s. 75. - Klej n, op. cit., s. 118.

114 Zob. Ówczesny [Uziębło], op. cit., s. 6. - Antonów, op. cit., s. VII.

115 Zob. zaświadczenie władz lekarskich guberni wileńskiej o przyznaniu Eustachemu Wróblewskiemu praw urzędnika medycznego niższej rangi. 20 VI 1857. BWLAN. Rkps 75-104, k. 8r-8v (w języku rosyjskim).

116 Zob. zaświadczenie władz lekarskich guberni wileńskiej o przyznaniu Eustachemu Wróblewskiemu pozwolenia na leczenie homeopatyczne. 1 IX 1859. Jw., k. 13r (w języku rosyjskim). 
Ogólnie rzecz biorąc, pan Wroblewski [!], będąc człowiekiem świetnego charakteru, ma wyjątkowe umiłowanie do pomagania cierpiącym i w szczególnych okolicznościach nie oszczędza pracy ani zdrowia, gdy niesie pomoc chorym ${ }^{117}$.

Jedynie Uziębło, dobrze zaznajomiony ze szczegółami biografii Wróblewskiego, pisał, że w młodości stanowczo opowiadał się on za alopatią (tradycyjnymi metodami leczenia).

Mąż Emilii, błyskotliwy, rozmowny, łatwo nawiązujący stosunki i lubiący towarzystwo („Dowcipny gawędziarz był z pana doktora Eustachego, a i winem też w gronie przyjaciół nie gardził" ${ }^{118}$ ), nawet piszacy wiersze okolicznościowe ${ }^{119}$, był również człowiekiem „niepospolitej umysłowości” ${ }^{120}$. Zajmował się nauką (homeopata, entomolog; mało tego: jak można wnioskować z dziennika jego żony, interesował się także birsztańskimi wodami mineralnymi). Mimo to nie należał do ani jednego prestiżowego towarzystwa naukowego w Wilnie. Już po śmierci Wróblewskiego syn Augustyn podarował, w r. 1895, wartościową kolekcję chrząszczy zebrana przez ojca nie Wileńskiemu Muzeum Starożytności czy Cesarskiemu Towarzystwu Lekarskiemu w Wilnie, lecz Muzeum Komisji Fizjograficznej Akademickiej - z zastrzeżeniem, by kolekcję tę przechowywano jako „Zbiór chrząszczów śp. dra Eustachego Wróblewskiego" i by wydano katalog zbiorów ${ }^{121}$. Kiedy po 1865 r. najwartościowszą część wileńskiej kolekcji muzealnej przewieziono do Moskwy, niejeden kolekcjoner decydował się na ofiarowanie swoich zbiorów krakowskim i warszawskim (a nie wileńskim) instytucjom. Z drugiej strony, tak jak Augustyn uwiecznił imię swojego ojca, nieco później podobnie postapił Tadeusz Stanisław, zakładając w 1912 r. Towarzystwo Biblioteki im. Eustachego i Emilii Wróblewskich. Uziębło podkreśla, że podstawą zbiorów Tadeusza Stanisława była biblioteka zgromadzona przez ojca, złożona $\mathrm{z}$ książek przyrodniczych i związanych $\mathrm{z}$ działalnością medyczną ${ }^{122}$. Wróblewski zmarł w Wilnie 9 VI $1891 \mathrm{w}$ wieku 66 lat ${ }^{123}$.

Najważniejszym źródłem do rekonstrukcji życia Eustachego Wróblewskiego jest jego spuścizna autobiograficzna. Najciekawszą jej część stanowi 77 listów przechowywanych w BWLAN, pisanych w latach 1861-1888 do żony oraz do synów Kazimierza i Tadeusza Stanisława ${ }^{124}$. Publiczną działalność Wróblewskiego najlepiej

Ibidem.

Ówczesny [Uzi ębło], op. cit., s. 6.

E. W r ó bl ew s ki, Sztambuch. 1857-1881. BWLAN. Rkps 9-150, k. 59r-59v, 62r-63v (wiersz dla Kazimiery Jankowskiej; wiersz dla Henryka Kurnatowskiego). Zob. też E. W róble w s ki, Wiersz dla Henryka Kurnatowskiego. 15 VII 1872. Jw., rkps 9-2349, k. 11r-11v.

Ówczesny [Uziębło], op. cit., s. 6.

List F. Kranza, przewodniczącego Komisji Fizjograficznej Polskiej Akademii Nauk w Krakowie do A. Wróblewskiego, z 20 I 1895, z Krakowa. BWLAN. Rkps 75-111, k. 52r. Na Litwie zachowało się zaledwie kilka reliktów poświadczających entomologiczne studia Eustachego Wróblewskiego. Zob. E. Wr óblew s k i, Zapiski entomologiczne. [Bez daty]. Jw., rkps 9-960, k. 1r-4r (w językach polskim i łacińskim).

L. U z [i ę bło], Biblioteka Mec[enasa] Tadeusza Stanisł[awa] Wróblewskiego. „Przewodnik Antykwarski” 1911, nr 5, s. 6.

Wiadomość wysłana do Józefa Bielińskiego o śmierci i pogrzebie Eustachego Wróblewskiego. 9 lub 10 VI 1891. BWLAN. Rkps 75-104, k. 23r (w języku francuskim).

E. W róblew s ki, Listy do Emilii, Kazimierza i Tadeusza Stanisława Wróblewskich. 1861-1863, 1881-1888. Jw., rkps 7-2039, 2011b, 1476a, 1478, 1481 (w językach polskim i rosyjskim). 
charakteryzuje jego sztambuch ${ }^{125}$. Ten specyficzny gatunek z zakresu autobiografistyki, będący integralną częścią ówczesnego życia codziennego, dziś stał się wartościowym źródłem literackim, artystycznym i historycznym, jako że ujawnia cechy charakteru właściciela albumu, jego upodobania oraz - co najistotniejsze - jego prywatne i publiczne kontakty. W tej pięknej książce, którą Eustachy otrzymał 27 III 1857 z okazji swoich imienin i która była potem uzupełniana aż do r. 1881, znajdują się podpisy Ludwika Kondratowicza (Władysława Syrokomli), Antoniego Edwarda Odyńca, Wacława Przybylskiego, Maurycego Krupowicza, Henryka Kurnatowskiego i innych. Wszystkie te osoby łączyło członkostwo Tymczasowej Komisji Archeologicznej w Wilnie. Jak wspomniano, formalnie Wróblewski nie należał do tej organizacji - watpliwe, by miejscowa władza przystała na udział w niej byłego zesłańca.

Album wskazuje nie tylko na duchową czy ideową bliskość Wróblewskiego z członkami komisji, lecz także na wyjątkową przyjaźń między nim a Syrokomlą. Najdobitniej Wróblewskiego charakteryzują w tym albumie nie te wersy Syrokomli, które przytaczane są przez niejednego badacza ${ }^{126}$, ale dwa słowa wpisane przez poetę 29 III 1857: „Oto mąż!...”127

Nie znajdziemy tych faktów w dziennikach Emilii Wróblewskiej. Działalność społeczną męża - z lat młodości, na zesłaniu, w Wilnie, towarzyszącą także wykonywaniu profesji lekarza - opisuje ona w kilku zaledwie zdaniach: „on jest prawym, szlachetnym, ogólnie szacowanym człowiekiem”; albo: „Życie jego - jego praca jest pełna pożytku dla bliźnich"128. Z drugiej strony, w dzienniku żony został wyraźnie zaakcentowany cyganeryjny styl życia Wróblewskiego - pod tym względem jego portret odmalowała ona podobnie jak Uziębło. Być może, diarystka z jej skłonnością do samotności, a nawet ascezy, stale czuła się obok męża istotą zwyczajną, prozaiczną, nie umiejąca zdobyć jego miłości: „ale nie widzi, nie uznaje we mnie towarzyszki życia” 129 .

W małżeństwie Emilia i Eustachy Wróblewscy przeżyli 30 lat i doczekali się siedmiorga dzieci - pięciu synów i dwóch córek. Dojrzały wiek osiagnęli dwaj synowie: Tadeusz Stanisław i Augustyn. Syn Władysław zmarł jeszcze w niemowlęctwie, Zygmunt nie przeżył czterech lat, Kazimierz siedemnastu. Ostatni z nich popełnił samobójstwo. Córka Stanisława żyła zaledwie cztery lata, a Maria zmarła $\mathrm{w}$ wieku lat osiemnastu ${ }^{130}$.

Całe dorosłe życie Emilia spędziła w Wilnie. Tu także zmarła - 23 XII 1886, w wieku 56 lat. Pochowano ją na cmentarzu Na Rossie, w grobowcu rodziny Wróblewskich. Tam spoczęli również jej matka Augustyna, ciotka Leokadia, mąż Eu-

Wróblews ki, Sztambuch, k. 1r-63v.

Zob. wpis W. Syrokomli (Wilno, bez daty). W: Wróblew ski, Sztambuch, k. 17r.: „Rozkazałeś mi pisać, więc piszę choć trocha / Bogdajbyś tak mię kochał, jak cię Wilno kocha”. Wpis ten przytaczali: Ów c ze s ny [U zi ię ł o], op. cit., s. 6. - [S. W a sylew s ki], Sztambuch-skarbnica romantyzmu. Ozdobiła J. H a r l a n d - Z a j a c z k o w s ka. Lwów-Warszawa [1922] (brak paginacji). Wpis W. Syrokomli (Wilno, 29 III 1857). W: Wróblewski, Sztambuch, k. 16r.

D2, k. 31v (Wilno, 15 I 1858); D2, k. 41v (Wilno, 23 II 1858).

D2, k. 32r (Wilno, 15 I 1858).

Więcej na ten temat zob. Sawkina, op. cit., s. 15. 
stachy, córki Stanisława i Maria, synowie Kazimierz i Tadeusz Stanisław. Groby Władysława i Zygmunta nie zachowały się - tak jak zmarłego w Paryżu Augustyna.

\section{Charakterystyka dzienników}

Sygnatury, chronologia, miejsce powstania

Diarystyczną spuściznę Emilii Wróblewskiej tworzy siedem zeszytów. Za tradycyjny dziennik moglibyśmy uznać trzy pierwsze rękopisy, pochodzące $z$ lat 1850-1870, dzisiaj przechowywane w „Zbiorze ogólnym” (lit. „Bendrasis fondas”) BWLAN (F 9). Numeracja jednostek w zespole nie odpowiada chronologii powstawania dzienników. Pierwszy dziennik, $z$ lat 1850-1855, ma sygnaturę 183, drugi (1856-1869) - 272, trzeci zaś (1860-1870) - 236.

Większość kobiet po zamążpójściu zazwyczaj porzucała pisanie dziennika. Zdarzały się jednak wyjątki. Jednym z nich była Emilia Wróblewska. W roku 1870, kiedy skończyła 40 lat, zdecydowała się nie pisać więcej, gdyż traktowała tę zmianę jako przejście do nowego etapu w życiu: okazało się, że jej ,ja” nie jest już tak wyraziste, że dość miała rozmów ze sobą o sobie - nawet w szlachetnym celu doskonalenia się moralnego. Wszystkie myśli od tej chwili kierować chciała tylko do dzieci:

W tym roku skończyłam lat 40 i zamykam swój dziennik. Dosyć pisać o sobie dla siebie, choćby w celu wykształcenia się moralnego. Odtąd żadna myśl wyłącznie mnie mająca na celu - już moje ja niesie ku zachodowi. Precz marzenia, troski, starania, chęci, tęsknoty, prace nawet choć najmniej egoistyczne. Wszystko jedynie dla dzieci. I dotąd one były jedynym celem mojego życia. Ale dziś o sobie zapomnić chcę zupełnie. Dla nich chcę żyć, pracować, kształcić się - wszelka przyjemność, wszelkie zajęcie, któreby do nich się wyłącznie się [!] nie odnosiło, odrzucam jako niewarte, niegodne [...]. Żegnam Cię, mój dzienniku - nie rzucam Cię, lecz pogadanki nasze inną przybierą postać ${ }^{131}$.

Nie udało się jej wypełnić tego zamierzenia. Wróblewska należała do kobiet, które nie mogły nie pisać. Dlatego też po 1870 r. swoje myśli przenosiła do dzienników adresowanych do dzieci - Tadeusza Stanisława, Marii i Augustyna.

Dziennik z lat 1859-1886, dla najstarszego syna, Tadeusza Stanisława, to najbardziej znany tekst autobiograficzny Wróblewskiej. Księga ta, podarowana synowi $z$ okazji pierwszych urodzin, tak jak pozostałe jej prywatne rękopisy przechowywana jest w tym samym „Zbiorze ogólnym” BWLAN (rkps 149).

Dziennik dla najstarszej córki, Marii (1860-1878), badacze penetrowali bardzo rzadko, choć rękopis ten nie jest mniej interesujący od dziennika dla Tadeusza Stanisława. Nie tylko dlatego, że to tekst pisany przez kobietę dla kobiety, lecz także dlatego, że stanowi przykład unikatowej postawy diarystycznej. Mam na myśli podwójnego adresata tego rękopisu - po śmierci córki Marii (28 IV 1878) Wróblewska długo do niego nie zaglądała, by potem wykorzystać go jako dziennik dla syna Augustyna. Wprawdzie zdażyła zrobić tylko jedną notatkę dla syna, 7 VII 1886 (przypomnijmy, że diarystka zmarła 23 XII 1886), ale nazywanie owego manuskryptu dziennikiem pisanym wyłacznie dla Marii nie jest precyzyjne. Jest on przechowywany w „Zbiorze ogólnym” BWLAN (rkps 9-152 ). 
Przy bliższym przyjrzeniu się rękopiśmiennej spuściźnie Emilii Wróblewskiej można dostrzec jeszcze jeden istotny fakt - to bynajmniej nie wszystkie jej dzienniki. Mam na myśli jeszcze dwa fragmentaryczne, ale mające wyraźne cechy diarystyczne, rękopisy, które nazwałabym dziennikami Emilii: kilka wpisów (rkps 311) sporzadzonych w $1867 \mathrm{r}$. w Londynie, po śmierci jej ojca, oraz literacko-refleksyjny, najbardziej wyjątkowy, zeszyt z r. 1884, zatytułowany Moje myśli (rkps 884). Diarystka traktowała go jako kontynuację dziennika zakończonego w 1870 r., jako próbe powrotu do systematycznego, codziennego rejestrowania swoich refleksji i działań - chciała „zdawać sobie systematycznie sprawę z [...] myśli i czynności”"132. Jednak zeszyt wybrany na dziennik jest dużo skromniejszy od pozostałych - to zwykły szkolny zeszyt w linie, w miękkiej, błękitnoszarej okładce.

Tak oto na cały 27-letni okres - 1850-1886 - przypada tylko 9-letnia przerwa (w latach 1873-1877 i 1879-1883 Wróblewska nie prowadziła dziennika w ogóle). Blisko 30 lat intensywnej twórczości. Łącznie Wróblewska pozostawiła po sobie 730 diariuszowych wpisów, $\mathrm{z}$ których 3 sporządziła w Londynie, $22 \mathrm{w}$ Połądze - w dość oryginalnych miejscach jak na kobietę pochodzącą z XIX-wiecznej Litwy; wszystkie pozostałe, tj. aż 705 - w Wilnie.

588 kart archiwalnych, 1181 stronic zapisanych nieszczególnie równym, trudno czytelnym duktem, często $z$ błędami, przede wszystkim interpunkcyjnymi, z poprawkami, kartami opuszczonymi w pośpiechu, nie zawsze $\mathrm{z}$ poprawną datą - Wróblewska prawie nigdy nie wskazywała dnia tygodnia ${ }^{133}$. Jednak ten zewnętrzny nieład zachwyca: pokazuje swobodnie płynąca myśl i, rzecz jasna, uczucie czyste, autentyczne. Zeszyty nie mają wewnątrz żadnych ornamentów, poza jednym, dwoma rysunkami naszkicowanymi naprędce: wieńcem kwiatów ozdabiającym datę ślubu czy krzyżykami oznaczającymi śmierć - najczęściej dzieci. Podobną właściwość, niedziewczęca, ma również sztambuch Wróblewskiej - bez żadnych artystycznych próbek ${ }^{134}$.

\section{Gatunki, adresaci i cele}

Spośród siedmiu znanych dzisiaj zeszytów dziennikowych Emilii Wróblewskiej pięć zaadresowała do siebie samej - ad se ipsum. Nie zdarzają się dzienniki bez adresata: nawet wtedy, kiedy diarysta sam sobie czyta dziennik, nie może nie stawiać na swoim miejscu kogoś innego. Dwa pozostałe zeszyty dzienników Wróblewskiej mają bardzo konkretnych adresatów: troje własnych dzieci. Dzienniki te nie są tak intymne, ale również mają swoją specyfikę - bliższą listowi.

Wyjątkowym podgatunkiem dziennika, rzadko wyodrębnianym przez badaczy, są dzienniki prowadzone dla dzieci. W wieku XIX teksty takie często pisały kobiety

E. W ró ble w s k a, Notaty różne „Moje myśli”. [1883-1884] (dalej: D5). BWLAN. Rkps 9-884, k. 1r (1883; nie wskazano dnia ani miesiąca wpisu).

133 Pod tym względem zupełnym przeciwieństwem dziennika Wróblewskiej jest diariusz P. z M onwid-Białłozorów Kończyny: Dziennik. 1841-1843. Państwowe Archiwum Historyczne Litwy (dalej: PAHL). Rkps 1135 20-397, k. 1r-250v; Dziennik. 1846-1847, 1851-1853. Jw., rkps 1135 20-398, k. 1r-203v. Dziennik ten, zwłaszcza jego pierwszy zeszyt, jest bardzo pedantyczny: charakteryzujący się kaligrafowanym pismem, z marginesami, bez jakichkolwiek skreśleń. 
pochodzące $z$ wyższych sfer. Związane to było z nową koncepcją społeczną dziecka, jego miejsca w rodzinie: kiedy zajęło ono centralna pozycję $w$ rodzinie i kiedy cała uwaga rodziców zwróciła się ku jego fizycznemu i duchowemu rozwojowi - na poziomie zarówno materialnym, jak i uczuciowym. Dzienniki pisane dla dzieci stanowiły wyraz tej mentalnej przemiany. Niestety, do naszych dni dotrwało tylko kilka dokumentów $z$ tego gatunku. Najistotniejszym celem takich diarystycznych tekstów była dydaktyka, ale w niektórych miejscach wyraźnie zaznaczała się w nich również codzienność - życie rodzinne, stosunki matki i dzieci, opieka nad dziećmi, ich rozwój fizyczny i intelektualny, położenie kobiety w rodzinie, rola rodziców i dziadków, pojawiały się także inne ważne informacje ${ }^{135}$. Specyficznym rodzajem dziennika dla dziecka jest dziennik pisany w podróży. Zazwyczaj diariusze takie adresowano do małego syna albo małej córki pozostałych w domu. Rodzice, jak gdyby kompensując krzywdę rozstania, wskutek którego dziecko nie mogło razem z nimi dzielić wrażeń z podróży (najczęściej z powodu wieku), prowadzili dla niego niewielkie dzienniczki podróży. Unikatowym przykładem takiego utworu jest dziennik Malwiny z Jeleńskich Oskierczyny (ok. 1810-1884) z r. 1859, powstały podczas jej podróży po Europie dla córki Franciszki ${ }^{136}$.

Wiadomo, że podwójnej wartości nabierają dzienniki pisane dla dzieci, które w przyszłości staną się znanymi osobami, postaciami historycznymi (tak jak w przypadku dziennika Emilii Wróblewskiej dla syna Tadeusza Stanisława) albo jeśli prowadzone przez utalentowanego diarystę - mają jakąkolwiek wartość literacką. Dzienniki Wróblewskiej dla dzieci mieszczą się również w tej ostatniej kategorii. Mogą konkurować tylko z dziennikami, które pisali Jan Niecisław Baudouin de Courtenay i jego żona Romualda $z$ Bagnickich Baudouin de Courtenay dla pięciorga swoich dzieci - dla każdego oddzielnie. Tak jak przystoi rodzinie językoznawcy, obok podawania informacji typowych dla gatunku małżonkowie szczegółowo rejestrowali rozwój języka ich dzieci - pierwsze słowa zapisywali w precyzyjnej transkrypcji fonetycznej ${ }^{137}$.

Dzienniki pisane dla dzieci stawały się nie tylko albumem własnej pamięci, lecz także wiecznym świadectwem miłości rodziców i ich troski, mało tego, przewodnikiem przez życie, który stale przypominałby dzieciom o wartościach wyniesionych z domu. Dlatego Wróblewska w dzienniku dla syna Tadeusza Stanisława pisze, że wyprowadzając się od rodziców, książkę tę będzie musiał wziąc jak najcenniejszą relikwię:

Gdy ci kiedy przyjdzie dom rodzicielski opuścić - proszę Cię i rozkazuję, mój synu, dziś malutki jeszcze, chodzić nie umiejący chłopczyno, byś z sobą zabrał tę pierwszą pamiątkę twej matki. Serce moje mówi mi, że ona, budząc w Tobie pamięć tych dni pięknych i niewinnych, kiedy matka była stróżem twej cnoty, kiedy czuwała nad twymi krokami, kiedy cię otaczała miłością i troskliwymi staraniami, nie dozwoli nigdy, by w twym sercu zagasła wiara, miłość ojczyzny, rodziny, ludzkości i cnoty. Tego pragnie Twa Matka, o to błaga Boga! Oby też wysłuchaną została!138

Zob. B a i r a š a u s k a i tè, Dzienniki szlachty litewskiej $z$ XIX wieku $w$ zbiorach wileńskich, s. 33. M. z Jeleńskich Oskierkczyna, Dziennik dla córki Franciszki. 1859. PAHL. Rkps 1135, 20-516, k. 1r-60v.

DTW, k. lr (Wilno, 1859; nie wskazano dnia ani miesiąca wpisu). 
Podobnie pisała również $\mathrm{w}$ dzienniku dla córki Marii. Nie tylko zapewniała o silnej matczynej miłości, lecz także dodawała, że ta książka będzie stale przypominać córce o najważniejszych zadaniach kobiety:

Ten pamiętnik podarowany Ci dziś przeze mnie na Gwiazdkę będzie Ci zarazem przypomnieniem, że przez miłość dla Matki, która Cię tak kochała, nigdy nie zaniedbasz pracy nad sobą, byś mogła zasłużyć na chlubną nazwę kobiety chrześcijanki $i^{139}$.

Tak jak dzienniki Baudouina de Courtenay i jego żony pisane dla dzieci, tak i dzienniki Emilii Wróblewskiej dla dzieci bardzo wyraźnie przekazują światopogląd samej diarystki, jej wartości. W tych tekstach egodokumentalnych najbardziej uwidacznia się podział na odrębne cele stawiane córce i synowi, tj. mężczyźnie i kobiecie: przeznaczeniem syna jest służenie celom wyższym, społecznym, a córki - bycie dobrą matką i chrześcijanką, tzn. poświęcenie się prywatnemu, rodzinnemu życiu. Choć ujawnia się w dziennikach przekonanie diarystki o różnych rolach kobiet i mężczyzn w społeczeństwie, Emilia Wróblewska nigdy - bardzo wyraźnie pokazuja to dzienniki - nie stawia Tadeusza Stanisława, pierworodnego syna, ponad córką Marią. Takie podejście było wówczas dość rzadkie. Klasyczny przykład eksponowania roli syna w rodzinie stanowi postępowanie Krystyny z Sadowskich Narbuttowej (1803-1899), żony historyka Teodora Narbutta, matki pięciu synów i trzech córek, która lubiła powtarzać: „Synowie to moja chwała! Córki zmieniają nazwiska" ${ }^{40}$. Wyrazem takich przekonań jest również epitafium na jej grobie na cmentarzu w miejscowości Šiauriai: „Matka synów”"141.

W każdym razie to od adresata zależy, $z$ jakim typem dziennika mamy do czynienia. Ale znacznie lepiej typ ten definiuja cele, dla których dziennik jest prowadzony. Wspomniałam już o intencjach pisania dzienników przeznaczonych dla dzieci. Częściowo określiłam także cele dziennika intymnego Wróblewskiej - to rozmowy ze swoim ,ja”. Według literaturoznawczyni Iriny Sawkiny to jak gdyby konwersacje ze swoim odbiciem w lustrze (,to jak pewnego rodzaju rozmowy z lustrem, ze swoim drugim "ja", wyobcowanym i zwróconym ku sobie"142). Rozmowa taka nie jest bez znaczenia, jej cel bowiem stanowi chęć poznania i doskonalenia siebie. W diariuszu Wróblewskiej widać to bardzo wyraźnie.

Duże znaczenie w dzienniku ma pierwszy wpis, który często zdradza prawdziwy powód prowadzenia go i który zazwyczaj powstaje na skutek ważnego zdarzenia. 5 VIII 1850 - będąc wówczas w Połądze, nieszczególnie wtedy typowym miejscu dla kobiet z litewskiej elity, jak już o tym mówiłam - Emilia Wróblewska sporządziła pierwszą notatkę. Dzień ów nie wyróżniał się niczym ani w życiu diarystki, ani w historii. Żałowała tego sama diarystka: „trzeba by poczekać jakiegoś dnia

E. z B en i ow s ki ch W ró blew s ka, Dziennik Marii Wróblewskiej przez Matkę [...] (1865-1878) (dalej: DMW; skrót został dostosowany do tytułu, choć dziennik miał dwóch adresatów: po śmierci córki Wróblewska wykorzystała go jako dziennik dla syna Augustyna). BWLAN. Rkps 9-152 , k. 2r (Wilno, 1 I 1865).

140 Z. Kow a le w s ka, Dzieje powstania lidzkiego. Wspomnienie o Ludwiku Narbucie. Odbitka z „Dziennika Wileńskiego” (1934, s. 68). - R. G r i š k a i tè, Teodoro dukté, Liudviko sesuo. „Metai” 1993, nr 6, s. 96.

141 T. Narbutaitè-M ončiunskienè, Prisiminimai. Jw., s. 112, przypis 87.

142 Sawkina, op. cit., s. 6. 
więcej znaczącego, pamiętnego jakim niebądź wypadkiem"143. Ale wartością pisania była wewnętrzna konieczność duchowego doskonalenia się, również w „zawodzie kobiety":

trochę się odmieniłam, lecz niezupełnie. I dobrze - teraz będziemy śledzić poruszenia swej duszy, myśli, serca, aby je wykształcić, ulepszyć, aby siebie podnieść do tej prawdziwej i jedynej wielkości, aby posiasść to prawdziwe szczęście, którym jest Cnota. Już jestem w wieku, w którym pojąć mogę wielkość zawodu kobiety. Nie schodzić więc nigdy z tego stanowiska, na którym mię Bóg umieścił, i być zawsze dla rodziny, dla przyjaciół, dla ludzkości tym, czym kobieta być powinna. Niech wszystkie marzenia do tego się odnoszą, to za cel jedynie mając ${ }^{144}$.

W tym miejscu nasuwa się porównanie $\mathrm{z}$ innym dziennikiem, którego autorką była Helena z Szymanowskich Malewska (1811-1861) ${ }^{145}$, żona wychowanka Uniwersytetu Wileńskiego i filomaty Franciszka Malewskiego. W diariuszu prowadzonym w latach 1827-1857 (całość nie dochowała się do naszych czasów) prawie nie sa poruszane zagadnienia samodoskonalenia się czy samopomocy. Znajdują się w nim natomiast zwięźle, ale zawsze skrupulatnie zarejestrowane wydarzenia codzienne, zaprotokołowane nazwiska spotkanych osób i tytuły przeczytanych książek. Inaczej mówiąc: to, co teoretycy diarystyki nazywaja „rachunkiem finansów” czy „Zwyczajem gromadzenia” ${ }^{146}$. Malewska dokonuje zapisów bardzo konsekwentnie, każdego dnia, nigdy nie zapomina podać daty, podaje nawet dzień tygodnia. Diarystka ta rzadko kiedy rejestruje w dzienniku problemy wewnętrzne, co jednocześnie podważa tezę, że faktografia i powściągliwość to cechy charakterystyczne dla męskiej diarystyki ${ }^{147}$. Bliski dziennikowi Malewskiej jest diariusz Kończyny z Monwid-Białłozorów. Ona również pisała codziennie, zawsze oznaczała datę, wskazując nie tylko dzień tygodnia, lecz także imię świętego, który przypadał na dany dzień, a ostatniego dnia miesiąca - również prawie zawsze - robiła ogólne zestawienie („Uwaga ogólna”). Z powodu tego modelowego wręcz porządku dziennik

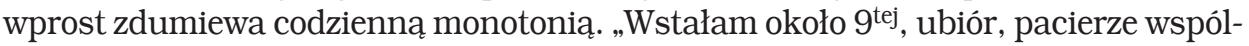
ne, herbata, Bossuet [najpewniej miała na myśli dzieło z 1648 r. Jacques’a Bénigne’a Boussueta Méditation sur la brièveté de la vie - R. G.], dziennik" - to jeden $\mathrm{z}$ charakterystycznych wpisów $\mathrm{w}$ diariuszu ${ }^{148}$.

Emilia Wróblewska nie prowadziła dziennika codziennie, lecz z kilkumiesięcznymi, nawet kilkuletnimi przerwami, prawie nigdy nie podawała dnia tygodnia, bardzo rzadko wpisywała miejsce, w którym sporządzała notatki. W porównaniu z objętościa jej dziennika - informacji faktograficznych jest w nim bardzo mało, dominują emocje, świat uczuć. Ten brak diarystycznego dokumentaryzmu odczuwała sama Wróblewska. Ale takie też były cele jej pisania: odnotowywanie - zamiast

D1, k. 2r (Połaga, 5 VIII 1850).

D1, k. 2r-2v (Połaga, 5 VIII 1850).

H. Szym a now ska - Ma lew s ka, Dziennik (1827-1857). Oprac. z autografu, wstęp, przypisy, noty Z. Sudolski. Konsultacja przy oprac. not biograficznych S. S. Łanda. Warszawa 1999.

Glins kis, op. cit., s. 17-18.

Zob. ibidem, s. 38.

P. z Monwid-Białłozorów Kończyna, Dziennik. 1841-1843, k. 27v (Wielki Ustiug, 4 II 1842, środa, dzień św. Andrzeja i św. Weroniki). 
wydarzeń dziennych czy też historycznych - swoich wewnętrznych przeżyć, upadków i wzlotów. Dziennik - to „pisanie siebie”, „konfrontacja ze sobą":

Dziennik mój mało zawierać może jakich bądź wypadków, ale on powinien być powiernikiem moich myśli, on słuchać będzie opowiadania mych walk wewnętrznych, mych upadków lub zwycięstw ${ }^{149}$.

Tydzień milczenia, to zaniedbanie rozmowy z sobą samą zawsze jest złym znakiem. Najczęściej wydarza się ono, gdy jestem w niezgodzie $z$ moim lepszym ja ${ }^{150}$.

Chwyciłam na koniec pióro, otworzyłam mój pamiętnik i zaczynam mówić z sobą, z samą sobą, uciekałam od siebie, od zajrzenia w te zakątki serca zakryte przed światem i ach, ja radam była zakryć je i przed własnym okiem ${ }^{151}$.

Funkcją dziennika była pomoc w osiagnięciu doskonałości moralnej, duchowej i intelektualnej. „Ulepszenie siebie” 152 - to słowa, które najczęściej pojawiają się w diariuszu Wróblewskiej. Ostatni raz pragnienie samodoskonalenia się wyraziła ona w 1884 r. - w tym czasie miała 54 lata. A więc jej dziennik zdecydowanie obala kolejna panująca opinię - że funkcje samodoskonalenia i samopomocy pełnią tylko dzienniki młodzieńcze ${ }^{153}$. $Z$ drugiej strony, ówczesne kobiety stale uczono, że część przynależnych im cnót była determinowana przez naturę, a pozostałą część miały osiagnąc ciagła praca, przez trwające całe życie samodoskonalenie. Nieustanne doskonalenie siebie było związane $z$ odpowiedzialnością za wychowanie dzieci. Od początku XIX w. kobieta w jeszcze większym stopniu postrzegała siebie jako przewodniczkę przez życie nie tylko córek, lecz także synów. Już Malewska pisała, że „obowiązek czuwania nad sobą samą” wiąże się z ogromną odpowiedzialnością właściwego pokierowania duchowym życiem jej syna (,wielkiego prawa kierowania jego sercem, jego uczuciami”"154).

Najważniejszym celem dziennika Malewskiej było odnotowywanie codziennych wydarzeń, a diariuszowanie Wróblewskiej stało się jak gdyby duchową terapią: „Nie mam o czym mówić, a jednak siadam do gawędy, tak mi brak przyjaznej, serdecznej duszy - z duszą rozmowy"155. Nieprzypadkowo dziennik nazywa „lekarstwem”"156, a jego pisanie - miłą i pożyteczną pracą:

Już obecny miesiąc ma się ku połowie, a ja ani chwilki nie poświęciłam czasu na pogadankę z mym pamiętnikiem. Zły to znak, jeśli już zaniedbuję tej rozmowy tak pożytecznej i tak słodkiej ${ }^{157}$.

Jesienią 1860 Wróblewska nosiła się $\mathrm{z}$ zamiarem spalenia dziennika, ale nie urzeczywistniła tego, ponieważ zrobiło jej się żal zapisków, które stały się już wspomnieniami. Jednakże najważniejszym powodem powstrzymania się od takiego

D3, k. 56v (Wilno, II 1861; nie wskazano dnia wpisu).

D1, k. 32r (Wilno, 5 X 1851).

Zob. Glinskis, op. cit., s. 38.

154 Szymanow ska-Mal ew s ka, op. cit., s. 337, 336 (Sankt Petersburg, 6 II 1834, wtorek).

155 D2, k. 37v (Wilno, 12 II 1858).

156 D1, k. 75r (Wilno, 17 IV 1854, sobota); D2, k. 8r (Wilno, 12 V 1856).

157 D2, k. 74v (Wilno, 11 IX 1858). 
czynu był fakt, iż dzięki pisaniu, komunikowaniu się z dziennikiem łatwiej znosiła niedogodności życia:

muszę wyznać, że jak tylko się wiernie trzymam tego sprawozdania przed sobą samą i mego usposobienia, nie tylko że mi lżej na duszy, ale ochotniej iść po drodze życia, jakoś jaśniej i rzeźwiej ${ }^{158}$.

W tym wypadku ciekawe okazało się porównanie omawianego dziennika $z$ diariuszem Anny z Oskierków Siwickiej (vel Anny Oskierczanki, ok. 1810-?), córki Pawła Oskierki, przewodniczącego szlachty z guberni mińskiej, powiatu mozyrskiego, i Franciszki z Jeleńskich Oskierkowej ${ }^{159}$. Siwicka pisała go w okresie panieńskim, by łatwiej znosić fizyczna niemoc i duchowe cierpienia. Przestała pisać, gdy wyzdrowiała.

Samokontrola - to również jedna z przyczyn popularności dziennika jako gatunku egodokumentalnego. Najczęściej dotyczyła zachowań diarysty, rzadziej - języka $^{160}$. Językowy aspekt pisania dziennika nie zajmował Emilii Wróblewskiej (w odróżnieniu np. od wspomnianej Oskierkówny). Dziennik pomagał tylko w utwierdzeniu się w swoich działaniach, w przezwyciężaniu wad:

Tak się gniewam na sobie, jeśli długo swego dziennika nie piszę, bo myśli ulatują, wrażenia się zacierają, a co więcej, rzadko sama z sobą rozmawiam, rzadko badam swoje postępowanie i samowolnie opuszczam tyle dobrych zręczności sprostowania swoich braków, podtrzymania chwiejącej się woli. Trzeba mi koniecznie nawyknąć do tej codziennej rozmowy z moim dziennikiem ${ }^{161}$.

Z dziennikiem diarystka rozmawia jak z „siostra” („moja droga Siostro”) ${ }^{162}$, „idealną przyjaciółką” („moja idealna przyjaciółka”) ${ }^{163}$, przyjacielem i powiernikiem (nazywa go ,jedynym [...] przyjacielem”164, „powiernikiem [...] myśli”165):

Piszę dziś jedynie dlatego, aby zacząć, aby jakkolwiek zawiązać rozmowę z moim od tak dawna opuszczonym, zapomnianym przyjacielem, a jedynym na tym wielkim świecie, jedynym, choć niemym, ale dobrym, cierpliwym, zawsze gotowym do wysłuchania moich skarg i żalow, moich marzeń, nie zawsze wesołych ${ }^{166}$.

Rozmowie $z$ tak cierpliwym i rozumiejącym przyjacielem szczególnie sprzyja deszczowy, wietrzny dzień (pierwszy znany nam wpis Wróblewska zrobiła podczas burzy nad Bałtykiem w Połądze) albo późny wieczór, kiedy wszyscy śpią i wokół

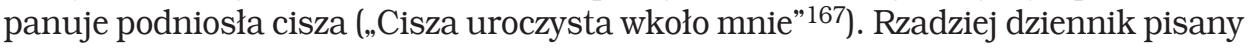

D3, k. 104v (Wilno, 13 XI 1864).

A. z O skierków Siwicka, Dziennik. 1837. PAHL. Rkps 1135 20-707, k. 1r-31v (w językach polskim i francuskim).

Zob. A. P a c e vi či u s, Juozapas Jurgis Hilzenas ir jo Dienoraštis: keli štrichai masono biografijai. W zb.: Laisvoji mūrininkija pasaulyje ir Lietuvoje: idéjos, istorija, asmenybés. Sud. V. J o gèla. Vilnius 2012, s. 187.

D1, k. 20r (Wilno, 2 III 1851).

D1, k. 30r (Połaga, 19 VII 1851).

Ibidem.

D1, k. 75r (17 IV 1854, sobota).

D1, k. 60v (Wilno, 23 I 1853); zob. też D2, k. 54v (Wilno, 20 IV 1858).

D1, k. 29r (Połaga, 19 VII 1851).

D2, k. 29r (Wilno, 6 I 1858). 
jest w wolnych, poobiednich godzinach: sztuka wymaga samotności, a dla kobiety to szczególnie rzadkie chwile ${ }^{168}$. Wróblewska utrwaliła w swoim dzienniku również okoliczności samego pisania. Oto jeden $z$ takich obrazów:

teraz na przykład siedzę u swego stolika, pod oknem, tuż przy mnie moje książki, które mnie rozumieją, a które ja również pojmuję. Matka moja coś nuci, chodząc po pokoju, a moje pióro biega po stronnicach mego dziennika ${ }^{169}$.

Lecz jakkolwiek byłyby istotne dla nas motywy prowadzenia dziennika, jakkolwiek ciekawa praktyka jego pisania, najważniejsza pozostaje jego zawartość, najautentyczniej, gdyż z pierwszej ręki, tu i teraz, charakteryzująca zarówno samą diarystkę, jak i jej świat, którego ten diariusz jest częścią.

\section{Dziennik jako odzwierciedlenie świata zewnętrznego}

Każdy badacz, który otwiera dziennik, odnajduje ukazany przez diarystę świat zewnętrzny, dziś stanowiący już historię, znane nazwiska z epoki. Spuścizna Emilii Wróblewskiej jest pod tym względem uboga. Gdyby nie zarejestrowano miejsca pisania w diariuszowych zeszytach, wyłącznie na podstawie kilku aluzji można by się domyślić, że kobieta ta żyła w XIX-wiecznym Wilnie. W dzienniku niewiele jest Emilii i jej miasta. Najwyżej jeden, dwa epizody: dni św. Kazimierza czy św. Piotra i Pawła, Boże Ciało, Ogród Bernardyński, Antokol, wileńska Kalwaria. Ale i o tym wspominała zazwyczaj tylko pobieżnie, w kilku zdaniach:

Dziś dzień Ś. Kazimierza, patrona Litwy. O, gorąco prosiłam za sobą i za całą bracią moją, aby ten Ś. młodzian uprosił nam miłość cnoty, a za nią pójdzie i szczęście ${ }^{170}$.

Nic nie pisałam o tym wspaniałym i uroczystym obrządku, który się w naszym obchodzi mieście w dzień Bożego Ciała. Ta cześć publicznie oddawana Bogu, te tłumy ludu cisnące się za swoim Panem, tak jak to niegdyś było, gdy przechodził ten Zbawca miasta i wioski, niosąc błogosławieństwo i pociechę ${ }^{171}$.

Byliśmy dziś z Eustachym za miastem, w lasku sąsiednim kościoła Ś. Piotra, corocznie w dzień ten zbiera się na to miejsce całe miasto ${ }^{172}$.

Chodzimy na przechadzkę - ulubionym naszym miejscem jest góra w botanicznym ogrodzie, wszystko tam macie: i plac do biegania, i hojdawki, i altanki, i widok przecudny na całe miasto ${ }^{173}$.

Od dwóch tygodni jesteśmy za miastem, na Antokolu, ale już tak daleko, że to już wsią nazwać można. Dzień cały jesteś na dworze, biegasz jak ptaszyna swobodna, jak tylko oczki otworzycie, już nie ma was w pokoju. Kąpiecie się, bo za ogrodem płynie Wilia ${ }^{174}$.

Zob. P. z Monwid-Białłozorów Kończyna, Dziennik. 1846-1847, 1851-1853, k. 34r (Łukinia, 8 V 1846, środa, dzień św. Stanisława): „Pisałam dziennik, odosobniwszy się choć na chwilkę".

D1, k. 53v (Wilno, 23 VIII 1852).

D1, k. 20v (Wilno, 4 III 1851).

D1, k. 46r (Wilno, 4 VI 1852).

D2, k. 67v (Wilno, 29 VI 1858).

DTW, k. 74v (Wilno, czerwiec 1869; nie wskazano dnia wpisu). Zob. też DMW, k. 22v (Wilno, 27 VI 1869).

DMW, k. 23r (Wilno, lipiec 1869; nie wskazano dnia wpisu). 
W tym miesiącu różneśmy zwiedzali okolice Wilna. Naprzód byliśmy w Kalwarii - czółnem płynęliśmy tam i na powrót wśród najokropniejszej ulewy, ale dróżki udało się nam odbyć za najpiękniejszej pogody. Widziałaś, Maryśko, te tłumy ludu, co z różnych stron się zbiegli dla uczczenia pamiątki Męki Chrystusa Pana ${ }^{175}$.

Nieco obszerniej diarystka opisała elektryzujące całe Wilno koncerty skrzypka Apolinarego Kątskiego (1825-1879) oraz wiolonczelisty Samuela Kossowskiego (1805-1861), które odbyły się w 1852 r. i które Wróblewska nazwała najpiękniejszymi chwilami w swoim życiu (,jest to jakaś cząstka rozkoszy nieba” ${ }^{176}$ ). Ciekawe, że skłaniała się ona nie ku słynnemu Kątskiemu, obsypywanemu kwiatami („bukiety sypały się gradem" ${ }^{177}$ ), ale ku starszemu o 20 lat i nie tak popularnemu Kossowskiemu („więcej mnie uniósł”" ${ }^{178}$ ). Zaledwie rok wcześniej tournée Kątskiego w Sankt Petersburgu opisała w swoim dzienniku również Malewska. Te okoliczności sprawiły, że owe dwa tak różne dzienniki diarystek jak gdyby „się spotkały”.

W dziennikach Emilii Wróblewskiej znajdziemy trochę informacji o działalności stowarzyszenia dobroczynnego św. Wincentego à Paulo w Wilnie ${ }^{179}$. Ale i tych faktów jest niewiele, jeśli brać pod uwagę zaangażowanie samej diarystki w działalność organizacji dobroczynnych. Wspomniałam już, że w dzienniku znajduje się kilka wzmianek o najbardziej może wstrząsającym wydarzeniu w popowstaniowym Wilnie - zamknięciu klasztoru wizytek, a dokładniej, o wygnaniu sióstr zakonnych do Francji. Wróblewska, uczennica pensji wizytek, przeżyła to wydarzenie ze szczególnym wzruszeniem:

W tym miesiącu kochane wizytki opuściły kraj i biedne wygnanki przeniosły się do Paryża. Zdawało mi się, że żegnam najbliższych moich, bo też i naprawdę z nimi straciłam przyjaciół, gdzie miałam radę, zasiłek dla ducha i w każdym razie życzliwość tak szczera, serdeczną i bezinteresowną, o jaką trudno na ziemi. Ale w każdym razie bądź wola Twoja, o Boże! Nie ja jedna tę stratę opłakuję, całe miasto po nich płacze ${ }^{180}$.

W dzienniku Wróblewska zapisała imiona dwóch sióstr zakonnych, z którymi łączyła ją szczególnie mocna przyjaźń - Marii Salezji Czapskiej i Marii Kazimiery Balińskiej ${ }^{181}$. Jak potwierdzają badania historyka Vytautasa Jogèli, zakonnice te były w spisie wygnanych wizytek ${ }^{182}$. Z klasztoru pod eskortą żandarmów i kozaków 12 czteroosobowych karet przetransportowało wizytki 5 grudnia wczesnym rankiem - żeby nie wywołać w mieście niepotrzebnych rozruchów - ulicami oddalonymi od centrum na wileńską stację kolejową.

Już Zbigniew Sudolski, który opracował edycję dziennika Heleny Malewskiej,

$$
15 \text { VII 1869). }
$$

Ibidem.

Ibidem.

D1, k. 45v (Wilno, 22 V 1852).

D3, k. 19v-20v (Wilno, 10 IV 1860), k. 24r-24v (Wilno, 22 IV 1860), k. 24v-25r (Wilno, 28 IV 1860), k. 78v-79v (Wilno, 5 II 1862).

D3, k. 114r (Wilno, marzec 1865; nie wskazano dnia wpisu).

D1, k. 60v (Wilno, 23 I 1853), k. 86v (Wilno, 28 I 1855).

V. J o gè la, Vilniaus vizitiečiu vienuolyno uždarymas. „Lietuvių katalikų mokslo akademijos metraštis" t. 32 (2009), nry 10, 12. 
zwracał uwage, że w diariuszu tym prawie nie ma opisów Sankt Petersburga, tylko jeden, dwa epizody, jak gdyby diarystka nie żyła w tym niezwykłym mieście. Całkowicie inne wrażenie robi dziennik Gabrieli Mohl-Basanowiczowej: przedstawia ona wszystkie ciekawe miejsca w rodzinnej Pradze. Pod tym względem dziennik Emilii Wróblewskiej jest w dużym stopniu bliższy dziennikowi żony Franciszka Malewskiego: mało w nim opisów miasta, w którym, poza kilkoma wyjątkami, diariusz powstawał. Nie ma w nim również wyrazistych portretów wilnian albo osób goszczących $\mathrm{w}$ tym mieście. Wspomniałam już, że nieco więcej uwagi diarystka poświęciła legendarnemu wileńskiemu nauczycielowi Aleksandrowi Zdanowiczowi, a także Teodorowi Tripplinowi - drugiemu $\mathrm{z}$ nich przede wszystkim $\mathrm{z}$ powodu jego związków z ojcem. Oczywiście, w jej wpisach znajdziemy również wzmianki o Józefie Korzeniowskim i Władysławie Syrokomli, i Adamie Pługu (właśc. Antonim Pietkiewiczu), ale tylko w kontekście przeczytanych książek albo obejrzanych spektakli183. W dzienniku Wróblewskiej niewiele znajdziemy portretów mężczyzn, nie tylko znanych, lecz także „zwyczajnych” - poza mężczyznami z jej rodziny, którzy dzisiaj w żadnym razie nie są dla nas „zwyczajni”. Więcej jest kobiet - przyjaciółek, znajomych. Wróblewska lubiła szkicować piórem ich dagerotypy - ale wyłącznie na początku, zwłaszcza w pierwszym dzienniku:

Znajomych mam niewiele, te jednak kilka osób, z którymi więcej jestem zbliżoną, muszą pomimo swej wiedzy i woli zostawić w moim dzienniku swoje dagerotypy, bo to teraz w modzie, spróbuję, może i mnie się uda ten nowy sposób chwytania podobieństwa. Spróbuję, a będzie mi to pamiątka - czasem miła, a zawsze korzystna ${ }^{184}$.

Niewiele - w każdym razie nie tyle, ile moglibyśmy się spodziewać - pisze Wróblewska też o Połądze, do której po raz pierwszy, w towarzystwie matki, przybyła jeszcze w 1849 roku. „Już siódmy rok przyjeżdżamy tu szukać zdrowia” - zanotowała w sierpniu $1855^{185}$. Tak więc jeździła tam dla kuracji: kapiele, również w morzu, stawały się coraz bardziej popularne - usilnie rekomendowali je ówcześni lekarze, także Tripplin ${ }^{186}$. Ale podróż z Wilna do guberni kurlandzkiej, do której należała wtedy Połaga, była długa i męczacca - tak jak powrót. Wróblewska nie miała własnego transportu, dlatego wynajmowała żydowskiego woźnicę. Jechała dwa tygodnie, czasami zaglądała do znajomych (zazwyczaj rodziców swoich uczennic $z$ pensji), niekiedy odwiedzała bardziej efektowne miejsca (np. dwór w Gorżdach słynacy ze swoich ogrodów ${ }^{187}$ ). Zawsze też robiła postoje podczas szabatu. Jak można sądzić na podstawie dziennika, te ostatnie szczególnie wyczerpywały jej siły:

Woźnica nasz, Izraelita, tam [tj. w zajeździe w Eragole] się zatrzymywał na święta. Pokoik malutki, towarzystwo nasze liczne, ciasnota więc była wielka, a do tego obkoło Żydzi jęczący, krzyczący (bo już 1852), k. 55r-55v (Wilno, 3 XII 1852). D1, k. 47r-47v (Połaga, 11 VII 1852, piątek).

D1, k. 88v (Połaga, 12 VIII 1855). 23 VII 1843, piątek, dzień św. Liboriusza).

D1, k. 6r (6 IX 1850).

D1, k. 10v (Wilno, 5 X 1850), k. 45v (22 V 1852), k. 52v (11 VIII 1852), k. 54v-55r (Wilno, 22 XI

Zob. B oł dy r e w, op. cit., s. 113. Tym można wyjaśnić również ciekawość Pauliny z Monwid-Białłozorów Kończyny: na wygnaniu, w dalekim Wielkim Ustiugu, z zainteresowaniem czytała informacje o tak mało znanym wówczas kurorcie - zob. Dziennik. 1841-1843, k. 188v (Wielki Ustiug, 
to oni i modlą się nawet $\mathrm{z}$ jękiem) do późna nas bawili. A w nocy ich dziateczki swymi wrzaski spać nam nie dawali ${ }^{188}$.

Dlaczego nigdy nie jeździła do popularnych Druskienik? Z jakiego powodu wybierała odległa Połagę, można się tylko domyślać. Ze względu na morze i ponieważ nigdy nie lubiła dużego towarzystwa, skłaniała się ku samotności, oddaleniu. „Bo ja jakoś nigdy [nie] umiem harmonizować ze światem”; „mnie trzeba ustronia, bo tam moje szczęście, tam mój właściwy żywioł”; „Nie chcę znajomości bliskiej ze światem" - takie słowa stale pojawiały się w dzienniku Wróblewskiej ${ }^{189}$. Mimo rosnącej popularności Połąa w tym czasie nie mogła równać się pod względem rozrywek z Druskienikami. Później, kiedy mąż Eustachy zaczął interesować się wodami mineralnymi, Emilia wybierała nie Druskieniki, lecz Birsztany. Nadal jednak ukochanym miejscem pozostanie dla niej Połaga - tam, do znacznie już odmienionego kurortu, wróci także pod koniec życia ${ }^{190}$.

Wspominałam, że o Połądze Wróblewska pisała niewiele. W tych lakonicznych notatkach znaleźć można jednakże drobiazgi, które znajdują się tylko w jej dzienniku. W pewnym sensie uzupełnia on obraz Połagi znany dotychczas badaczom na podstawie informacji ogłoszonych w 1828 r. przez Jana Tadeusza Bułharyna i w r. 1840 przez Adama Ludwika Jucewicza ${ }^{191}$. Właśnie w diariuszowych rozmowach Wróblewskiej z jej własnym ,ja” znajdziemy również kilka faktów mówiących o warunkach, jakie mieli kuracjusze, o kapielach w morzu (nawet wieczorami), o spacerach, zabawach tanecznych (nazywanych resursami), o karnawałach (maskaradach), o wycieczkach do pobliskiej Kretyngi (organizowano je także w wersji pieszej). Natrafimy też na opis wielkiego pożaru, który wybuchł w 1854 r. w Kretyndze, i przerażenia, jakiego doświadczyli mieszkańcy Połagi, obserwujący duży pożar w tym samym roku w Kłajpedzie (niem. Memel) ${ }^{192}$. Rozmiary ostatniego adekwatne były do uczuć diarystki zarejestrowanych $\mathrm{w}$ dzienniku - wówczas $\mathrm{z}$ panoramy miasta zniknęły trzy kościoły, pięć szkół, 83 magazyny, kwartały z domami mieszkalnymi i zabudowania gospodarcze ${ }^{193}$. Ciekawe wyjaśnienie, być może odzwierciedlające zbiorową opinię, podaje Wróblewska na temat przyczyn pożaru w Kłajpedzie:

Jak nam potem powiedziano, że to się Memel pali, a w mieście tak ludnym, zajętym jedynie handlem i spekulacją, może było wiele złota nagromadzonego zdzierstwem i krzywdą drugich. Bóg niszczył te zbiory i oczyszczał ludzi od nieprawnie nabytych zysków ${ }^{194}$.

Należy żałować, że w miejscu, w którym Wróblewska opisuje pożar w Kłajpedzie, stronice dziennika zostały wyrwane. Pozostały za to wszystkie inne notatki, histo-

D1, k. 7r (Wilno, 6 IX 1850).

D1, k. 17r, 17v (31 I 1851), k. 62v (Wilno, 12 II 1853, czwartek).

Zob. E. W róblew s k a, listy z Połąi do Wandy z Wolskich Umińskiej w Warszawie. PAHL. Rkps 7-228: 6(18) VII 1881, k. 6r-7v; 9(21) VII 1881, k. 8r-9v; 15(27) VII 1881, k. 10r-11r.

Więcej o historiografii kurortu w Połądze zob. M. O mil a n ow s k a, Nadbałtyckie Zakopane. PoŁaga w czasach Tyszkiewiczów. Warszawa-Sopot 2011, s. 11-14.

D1, k. 79r-82r (Połaga, 26 IX 1854).

Zob. V. V a r e i k i s, 99 Klaipédos miesto istorijos / 99 Stories abaut Klaipéda / 99 Geschichten der Stadt Klaipéda. Klaipèda 2008, s. 29.

D1, k. $81 v$ (Połaga, 26 IX 1854). 
rycznie może najbardziej wartościowe, z okresu połąskiego, w których diarystka zarejestrowała wizyty biskupa Macieja Wołonczewskiego (lit. Motiejaus Valančiaus) - 1 VIII 1852 w Połądze i 2 VIII w Kretyndze. Wróblewska zawsze nazywa go tylko Biskupem, nie wymienia ani imienia, ani nazwiska:

Dnia tego była w Połądze wielka uroczystość. Biskup przyjeżdżał odwiedzić i tą cząstkę swojej owczarni. Ruch był wielki w miasteczku, bo rzecz to była rzadka i już od lat 14 nie mieli szczęścia widzieć swego pasterza. A któż nie przyzna, że dobry Pasterz zasługuje na miłość i hołdy swoich owieczek. Gdy się zbliżył Biskup, wyszli naprzeciw niego $\mathrm{z}$ choragwiami i krzyżem. 12 dziewcząt ubranych w bieli sypało mu kwiatki pod nogi. On błogosławił korzący się lud przed nim i witał ich jak wita Ojciec swe dziatki. Pobożny to lud ta Żmudź, lecz formę tylko pojmuje i formy się tylko trzyma, wiele jest łasyrajstwa w ich pobożności, krzyże, które co krok spotrzegać się dają, różańce, bez których żaden obejść się nie może, te długie modlitwy, te częste spowiedzie każą nam wnosić, że tam gdzie nawet lud prosty tak się do Boga garnie, być musi siedlisko poczciwości i cnoty, lecz nie tak jest, niestety ${ }^{195}$.

Jak wskazują Namų užrašai (Zapiski domowe) Wołonczewskiego, tego dnia w Połąze biskup udzielił sakramentu bierzmowania 715 osobom, a kolejnego w Kretyndze, podczas święta Porcjunkuli, ważnego dla franciszkanów i bernardynów, czy Matki Boskiej Anielskiej - nawet 1453 osobom ${ }^{196}$. Sakramentu udzielił też Emilii Wróblewskiej:

wielka tam doroczna uroczystość podwójną wtedy była, bo Biskup jej przewodniczył. Byłyśmy u Spowiedzi i Komunii. Raz pierwszy i ostatni znajdowałam się w podobnym feście. Ani jednego zmówić nie mogłam pacierza - myślałam, że się uduszę od gorąca i mocnego zapachu kwiatów, których to każda kobieta mieć musi dobry bukiet w ręku. Biedni księża, zupełnie zmęczeni, lecz jakże ogromne ofiary odbierają w dzień ten od włościan. Kto nie zna tego zwyczaju, mógłby pomyśleć, patrząc, że to jest dzień targowy - tyle wołów, owiec, miodu, lnu, itd. Rozsyłają zawsze bernardyni te datki i innym klasztorom - lud tu bardzo zamożny, bo i ziemia złota, i bliskość granicy niemało się do wzbogacenia ich dopomaga. Gdyśmy wróciły z Kretyngi, czułyśmy się bardzo znużone, ale każda z nas przez grzeczność nie chciała się udać na spoczynek ${ }^{197}$.

Oba te wpisy są niemal najwartościowszą dokumentarną częścią dzienników Wróblewskiej, zaświadczającą o pasterskiej atmosferze pracy Wołonczewskiego.

W tych obszernych diariuszach takie materiały pojawiają się bardzo rzadko. Arvydas Pacevičius, szczegółowo analizując dziennik Józefa Jerzego Hylzena (vel Hilzen vel Hielsen vel Hülzen, 1736-1786), pisał, że opowieść tego diarysty „w większym stopniu niż jego dotyczy innych" ${ }^{198}$. U Wróblewskiej odwrotnie - najwięcej miejsca autorka poświęca sobie. Jest rzeczą oczywistą, iż zasada ta dezaktualizuje się w przypadku dzienników pisanych dla dzieci, ale o tym zadecydowała specyfika tego typu diariuszowania. Glinskis, rozważając faktograficzną, dokumentarna wartość dzienników, odwołuje się do propozycji francuskiego filozofa i epistemologa Georges'a Gusdorfa, by oddzielać dziennik intymny od tzw. zewnętrznych, tj. bardziej nastawionych na wydarzenia zewnętrzne, a nie na świat wewnętrznych przeżyć diarysty ${ }^{199}$. Oczywiście, takie rozgraniczenie jest możliwe, lecz nie ma

D1, k. 49v (Połaga, 5 VIII 1852).

196 M. V a l a n či u s, Žinios apie vyskupo Motiejaus Valančiaus pastoracinius darbus. W: Namu užrašai. Sud. A. Pra šm antait è. Vilnius 2003, s. 725.

197 D1, k. 49v-50r (Połaga, 5 VIII 1852).

198 Pa c e viči u s, op. cit., s. 187: „pasakojimas yra daugiau ne apie save, o apie kitus”.

199 Glinskis, op. cit., s. 40-41. 
dziennika intymnego, w którym w ogóle nie znaleźlibyśmy opisów świata zewnętrznego, tak jak nie istnieje dziennik eksternalny, w którym nie odzwierciedla się wewnętrzny świat diarysty. W idealnej sytuacji - i takie dzienniki na ogół stają się standardowymi w literaturze pięknej - diarysta potrafi utrzymać równowagę pomiędzy tymi tak różnymi przestrzeniami. Wróblewskiej rzadko kiedy udawało się uzyskać tę harmonię: najczęściej jej wewnętrzne problemy dominowały nad światem zewnętrznym, w najlepszym wypadku o istotnych wydarzeniach historycznych opowiadała poprzez emocje. Również o patriotycznych manifestacjach religijnych w 1861 r. i o uwolnieniu chłopów od pańszczyzny 19 II 1861:

Godłem 1861 r. jest krzyż i cierniowa korona. Ziemia nasza cała inną przybrała postać i barwę. 1861 r. jest rokiem przebudzenia się narodu całego, epoką wejścia w siebie, epoką uznania własnych uchybień i wejścia na drogę nam właściwą, epoką poczucia konieczności zbratania się z młodszą bracią, epoką idei równości, co tak rozpromieniła biedną naszą ziemię, tak ją uszlachetniła. Piękny to rok dla kraju naszego ${ }^{200}$.

Drzemić nie wolno! Dziś wszyscy budzą się do czynu. I ja ze wszystkimi! ${ }^{201}$

Albo o powstaniu styczniowym - drugim po wspomnianej reformie uwłaszczeniowej, a może nawet pierwszym, wydarzeniu XIX stulecia:

Nie pisałam długo, bo boleść gniotła serce. Przybita, zbolała, spłakana, o niczym pomyśleć nie mogłam, a uczuć przepełniających duszę dziś i papierowi martwe śmiało powierzyć nie można. Zrazu bolałam, płakałam, chorowałam, dziś, gdy cios po ciosie uderza bez wytchnienia, bez przerwy, zmężniało i zahartowało się serce - nic go nie przestrasza, nic nie roztkliwia, a wszystkie klęski, co jak grad sypią się dokoła, więcej dodają męstwa i gotowości na wszystko, co najdotkliwiej ranić może człowieka. Śmierć sama dziś straciła całą swą okropnośćco2.

W pozostałych 11 tak ważnych dla nas wpisach z $1863 \mathrm{r}$. Wróblewska daje upust wyłącznie emocjom. Uczucia tylko i rozliczanie się z samowychowania i podróży - do zagranicznych kurortów, Londynu, Paryża. Nie wiemy, co widziała ani z kim się spotkała, a nieraz nawet i dokąd jeździła. To kolejna cecha wyróżniająca tę diarystkę, gdyż kobiecą literaturę egodokumentalną charakteryzuje właśnie skrupulatne przedstawienie takich podróży.

\section{Dziennik jako zapis kobiecej codzienności}

Badacze zajmujący się historią codzienności interesują się trybem życia kobiet, a zwłaszcza jego subiektywnym aspektem - uczuciami, doświadczeniami, emocjami. Skomplikowana jest jednak rekonstrukcja codzienności kobiet - dużo trudniejsza niż w wypadku osób z jakiejkolwiek innej grupy czy warstwy społecznej albo też odrębnych społeczności. Zazwyczaj kobieta niechętnie „gloryfikuje”, „wychwala” siebie w swoim codziennym życiu i to, co działo się w jej domu (salonie, kuchni, spiżarni), najczęściej wymazywano z pamięci historycznej:

Nie ma ona skłonności do mówienia o sobie, do wypowiadania siebie na głos, do określania siebie; jak każda inna kobieta nigdy nie miała skłonności do nazywania swoich nieświadomych kobiecych 
manii i fobii oraz do dzielenia się nimi (zwłaszcza na piśmie). O ile codzienność mężczyzn zawsze jest gotowa do pokazania się na uroczystym przyjęciu w sali pałacu albo na polu bitwy, o tyle otoczenie kuchni, pokoju dziecięcego, świetlicy, tym bardziej spiżarni czy strychu, tj. przestrzeni codzienności kobiet, zazwyczaj wymazuje się z pamięci historycznej ${ }^{203}$.

W swoich dziennikach Wróblewska niewiele mówi o „czystej” codzienności kobiety -zaledwie jeden, dwa wpisy poświęca porządkom domowym, pracom ręcznym, stosunkom ze służbą, spacerom, rodzinnym i kalendarzowym świętom. Nieco więcej tego rodzaju szczegółów umieszcza w dziennikach dla dzieci, ale i tam nie są one dominujące. Wróblewska, inaczej niż np. Paulina Kończyna, nie lubiła pisać o tym, co zwyczajne, monotonne:

Tydzień przebyłam bez zdania sprawy z mego postępowania, z mych myśli, wrażeń, bo wypadki jakieś szczególne nie przytrafiają się prawie nigdy w życiu tak cichym i monotonnym jak moje ${ }^{204}$.

Dlatego na podstawie tylko kilku dziennych notatek możemy wyobrazić sobie wnętrze domu Wróblewskiej - oto np. wpis z czasów panieńskich:

Ciocia kochana przygotowała na me przybycie ustronny kacik, zaopatrzyła we wszelkie sprzęciki do mej wygody potrzebne, pamiętała o tym, co lubię i czego żądałam; jest i krzyżyk z kropielnicą nad mym łóżkiem i w głowach wisi Matka N. Ostrobramska. Jakże czuję jej dobroć, jak wdzięczną jej za tą pamięć jestem ${ }^{205}$.

O domowym otoczeniu Wróblewskiej, już zamężnej, wiemy jeszcze mniej. Wydaje się, że jedynym luksusowym przedmiotem w domu był fortepian ${ }^{206}$. Porządków domowych nie lubiła. Nie interesowała się też pracami ręcznymi, które uznawano za nieodłączny element życia kobiety - nie tylko ze względu na praktyczne korzyści, lecz także dlatego, iż prace te traktowano jako środek do utrzymania duchowej harmonii, jako pewne antidotum na codzienne troski ${ }^{207}$. W połowie XIX w. kobiety - zwłaszcza skłaniające się ku aktywności intelektualnej - coraz częściej sprzeciwiały się temu obowiązkowi ${ }^{208}$. Taki niebezpośredni protest odnajdujemy również w diariuszach Wróblewskiej. Dla kobiet piszących, czytających - a do tej grupy Wróblewska się zaliczała - był to nieprzyjemny obowiązek. Także jej córka Maria odczuwała podobny wstręt do robótek ręcznych ${ }^{209}$. Z całkowicie odmienną postawą spotkamy się w dzienniku rówieśnicy Marii - Gabrieli Eleonory Mohl-Basanavičienė (Maria urodziła się w 1860 r., Gabriela - w 1861): „Najchętniej zajmuję się swoimi

N. L. Puszkari ew a, Istorija powsiedniewnosti: priedmiet i mietody. „Socyalnaja istorija. Jeżegodnik" 2007, nr 9, s. 53.

D2, k. 25v (Wilno, 26 XII 1857).

D1, k. 82r (Wilno, wrzesień 1854).

Zob. D2, k. 23v (Wilno, 14 XII 1857).

Zob. B ołdyrew, op. cit., s. 213. Charakterystyczne są słowa H. z Bécu Januszewskiej napisane po stracie córki (T. i H. J a n u s z e w s c y, list do J. Mianowskiego, z 14 X 1832 〈dopisek H. Januszewskiej〉. W: Listy Teofila i Hersylii 〈z domu Bécu〉 Januszewskich do Józefa Mianowskiego 〈1829-1837〉. Z autografów wydał, wstępem i uwagami opatrzył L. M é ye t. Warszawa 1897, s. 31): „Ja teraz po całych dniach siedzę nad kanwową robotą i to nieustanne liczenie krzyżyków nie daje, niż myśleć, a tego mi właśnie potrzeba”.

Zob. A. W. Bi eło w a, „Czetyrie wozrasta żenszcziny”. Powsiedniewnaja żyzń russkoj dworianki XVIII - sieriediny XIX w.w. Sankt-Pietierburg 2010, s. 289.

Zob. DMW, k. 3v (Wilno, 1 I 1865). 
pracami ręcznymi, ponieważ wtedy nie przeszkadzają mi moje myśli” ${ }^{210}$. Dla tej ostatniej prace ręczne stanowiły jeden ze sposobów spędzania czasu tylko ze sobą, w pewnym sensie podobny do diariuszowania.

Emilii Wróblewskiej trudno było znaleźć wspólny język ze służbą i jest to jeden z najczęściej pojawiających się problemów życia codziennego w jej tekstach egodokumentalnych. Nieodpowiednie zachowanie służby, niedokładne wykonywanie pracy, ciągłe zmiany w zespole służących - to nieodłaczne elementy jej codzienności (ale nie tylko jej). Dlatego dziennikowe wpisy dotyczące tych problemów zazwyczaj są dość długie ${ }^{211}$. Konflikty ze służącymi sprawiały, że Wróblewska czuła się stale nieszczęśliwa ${ }^{212}$. Miała jednak w zwyczaju przede wszystkim w sobie szukać przyczyny złych stosunków z „braćmi i siostrami” oddanymi pod jej opiekę:

Dom mój jest moim państwem, wszystko w nim ode mnie zależy - domownicy są mymi braćmi i współpracownikami, ważną więc jest rzeczą, by umieć cichość, pokój i jedność zachować, a przy tym ład i porządek utrzymać ${ }^{213}$.

Stosunek mój do sług zawsze jest niedobrym. One są nieporządne, leniwe, opryskliwe, ale jakże wiele w tym mojej jest winy ${ }^{214}$.

W roku 1860 Wróblewska zamierzała nawet zorganizować specjalną szkołę dla służby („Ja [...] ciaggle marzyłam o utworzeniu jakiego zakładu dla wychowania dobrych sług"215). Nie miała jednak ani środków, ani umiejętności, by nią pokierować, dlatego szybko pomysł ten zastapiła innym: postanowiła przetłumaczyć na język polski książki dotyczące stosunków służby z domownikami. Wkrótce porzuciła i ten pomysł, zresztą tak jak większość swoich literackich prac ${ }^{216}$. Do dzisiaj zachowało się jedynie 6 zasad - wymyślonych przez nią samą - komunikacji pani domu ze służącymi. Ostatnie zalecenie: „Żadnej sobie w tej mierze nie dozwolić słabości, jakkolwiek by to mnie kosztować miało" - pokazuje, że ta sfera życia codziennego naprawdę nie była mocną stroną Wróblewskiej ${ }^{217}$.

Dość wyrazisty w dziennikach, choć pod względem ilościowym nie zajmuje wiele miejsca, jest również temat chrzcin i urodzin dzieci. Dla nas dzisiaj najważniejsze są opisy chrzcin i pierwszych urodzin Tadeusza Stanisława. Przyszły znany adwokat miał sześcioro rodziców chrzestnych - to wskazuje na wysoki status społeczny Wróblewskich, chociaż czasami w ceremoniach takich uczestniczyło pięć albo więcej par rodziców chrzestnych ${ }^{218}$. Matką chrzestną pierworodnego zazwyczaj

Mano tèvyné - prie jo širdies, s. 100 (Praga, 24 II 1884, piątek).

Zob. D2, k. 20v (4 XII 1857 albo 5 XII 1857, albo 6 XII 1857; kartka przed tym wpisem została wyrwana), k. 29v-30v (Wilno, 11 I 1858), k. 30v-31r (Wilno, 12 I 1858), k. 59-60v (Wilno, 2 VI 1858), k. 62r-62v (Wilno, 8 VI 1858), k. 65r-65v (Wilno, 16 VI 1858); D3, k. 43v-45v (Wilno, 16 IX 1860).

Zob. D2, k. 20v.

D2, k. 62v (Wilno, 8 VI 1858).

D3, k. 44r (Wilno, 16 IX 1860).

D3, k. 7r (Wilno, 4 II 1860).

Zob. D3, k. 12r (Wilno, 5 III 1860).

D3, k. 45v (Wilno, 16 IX 1860).

Zob. B ołdy rew, op. cit., s. 268-269. Historyczka A. Praš ma n ta i te (Kunigaikščio Bogdano Oginskio (1848-1909 m.) krikšto ir krikštynu šventès intriga: faktai ir interpretacijos. W zb.: Kunigaikščiai Oginskiai Lietuvos istorijoje. Kultūrinès veiklos pédsakais. Sud. R. Šmig els ky tè - 
była babka - najczęściej ze strony matki. Tak stało się i tym razem: podczas chrztu w kościele św. Jana (w nim właśnie odbywały się najważniejsze wydarzenia w życiu rodziny Wróblewskich) Tadeusza Stanisława trzymała do chrztu Augustyna ${ }^{219}$. Wróblewska nie opisała świętowania chrzcin odbywającego się w domu, ale za to odnotowała pierwsze urodziny syna i prezenty, które wtedy mu podarowano ${ }^{220}$.

Wróblewska podała w dziennikach całkiem sporo szczegółów dotyczących prezentów, zwłaszcza dla dzieci. Kobiety w swoich egodokumentach zazwyczaj skrupulatnie opisywały takie przedmioty, miłe zarówno dla nich samych, jak i dla innych domowników. Dzieci tradycyjnie otrzymywały ubranka, buciki, łyżeczki z monogramami, książki itp. Wydaje się, że wyłącznie litewską tradycją były skarbonki, wręczane dziecku zaraz po jego przyjściu na świat. Tak też ojciec Tadeusza Stanisława Wróblewskiego już dzień po narodzinach syna przyniósł mu pierwszy prezent - zarobione w ciagu dnia srebrne monety, które, za radą żony, wsypał do glinianej skarbonki i wręczył mu jako zalążek jego „kapitału” (,założono węgielny kamień funduszów malutkiego chłopczyny!"221). Takie skarbonki były modne nie tylko w rodzinie Wróblewskich. Ich zawartość odnotowywano w specjalnych rejestrach ${ }^{222}$. W rodzinach rosyjskiej szlachty panował inny zwyczaj: każda osoba odwiedzająca kobietę w połogu zawsze zostawiała jej symboliczną sumę - wierzono, że w przeciwnym razie matce albo noworodkowi będzie grozić śmierć ${ }^{223}$.

W miarę jak święta stawały się coraz istotniejszym aspektem relacji emocjonalnych w życiu rodziców, dzieciom poświęcano coraz więcej uwagi. Oto echo dziewiątych urodzin córki Wróblewskiej, Marii:

Miałaś dziś gości. Zrobiłam wam podwieczórek w ogrodzie botanicznym na ulubionych wam górach. Było was z Guciem [tj. Augustynem Wróblewskim] jedenaścioro. Toż to się nabawiliście - w różne gry, zaledwie po ósmej wróciliśsie do domu na mleko kwaśne, herbatę i cukierki. Rzadko się to wam zdarza, mało macie znajomych, ale Mama i Tatko jak tylko mogą radzi Wam zrobić przyjemnośćc ${ }^{224}$.

Wspominałam, że w dziennikach Wróblewska niewiele pisała o wszystkich tych szczegółach codzienności kobiecej, a w szerszym znaczeniu - również rodzinnej, zwłaszcza dotyczących trybu życia. Diarystka jeszcze mniej miejsca poświęciła intymnemu aspektowi codzienności - ciaży i okresowi połogu. Te dwa stany są nieodłącznym elementem życia kobiety, ale informacje o nich niesłychanie rzadko

- Stuki en è. Vilnius 2010, s. 236) przywołuje także wyjątkowy przypadek z r. 1853, tj. mający miejsce zaledwie 5 lat wcześniej, kiedy to księcia Bogdana Ogińskiego podawało do chrztu w Retowie około 2000 rodziców chrzestnych, a 8 par wpisano do metryk chrztu.

Zob. DTW, k. 2v (wpis wprowadzający, 1859; nie wskazano dnia ani miesiąca wpisu).

Ibidem, k. 4v (1859; nie wskazano dnia ani miesiąca wpisu).

DTW, k. 2v (wpis wprowadzający, 1859; nie wskazano dnia ani miesiąca wpisu).

Zob. B a ir a š a u s k a it ė, Dzienniki szlachty litewskiej z XIX wieku w zbiorach wileńskich, s. 36. Najciekawszym przykładem takiego dokumentu jest wymieniony przez badaczkę rejestr prowadzony dla Medarda Kończy (syna). Zob. P. z Monwid-Białłozorów Kończyna, Rejestr oszczędności Medarda Kończy (syna). 23 VIII 1839 - 5 VIII 1843. PAHL. Rkps 1135, 18-6, k. 3r-27r. Matka nie ogranicza się jedynie do samych rachunków, ale również opisuje obrazowo dni, w których do skarbonki wkładano nowe monety, i wydarzenia wiążące się z życiem rodziny, zwłaszcza syna. W ten sposób dokument o charakterze finansowym staje się dziennikiem pisanym dla syna.

Zob. Bi ełow a, op. cit., s. 410-411.

DMW, k. 22v (Wilno, 27 VI 1869). 
można znaleźć zarówno w dziennikach, jak i w listach ${ }^{225}$. Także nieczęsto ciężarna kobieta pojawiała się w ikonografii. Badacze zazwyczaj tłumaczą to faktem, że dla kobiet był to tak zwyczajny, naturalny stan, że traktowały go jako niewart opisywania $^{226}$. Podobnie stało się w przypadku osobistych dokumentów Wróblewskiej. Jeśli chce się dotrzeć do informacji na temat tego szczególnego okresu w życiu kobiety, często trzeba niezwykłej uwagi, umiejętności odczytywania zmetaforyzowanej narracji. Według Natalii Puszkariowej korzystne byłoby przyjęcie pozycji współautorki dziennika, świadomego nieutrzymywania dystansu i odrzucenie dążenia do całkowitego obiektywizmu ${ }^{227}$. Ta rekomendacja znakomicie pasuje do dzienników Wróblewskiej. Ale jakkolwiek diarystki unikały mówienia o oczekiwaniu dziecka, w dzienniku nigdy nie zapominały o odnotowaniu jego narodzin.

Pisałam już, że Wróblewska urodziła siedmioro dzieci - pierwsze, kiedy miała lat 28, a ostatnie - w wieku 42 lat. Porody przypadły więc na okres 1858-1872. Rodziła co dwa lata, tylko w ostatnim przypadku - po 4-letniej przerwie. Wróblewska nie była wyjątkiem: niektóre współczesne jej szlachcianki rodziły 15, 19, 20, a nawet 22 razy $^{228}$. W dziennikach diarystki odnalazłam zaledwie 11 notatek, na których podstawie przynajmniej częściowo można zrekonstruować jej odczucia przed porodem i po nim. Tylko jeden wpis - dokonany natychmiast po narodzinach Tadeusza Stanisława - ujawnia pozytywne nastawienie diarystki ${ }^{229}$, wszystkie inne są przesycone strachem, niepewnością, lękiem przed bólem po porodzie i depresyjnym nastrojem: „O Boże, ja będę silna, ja będę mężna. Nie opuszczaj mnie, nie odmawiaj swego błogosławieństwa, zlej je szczególnie na dziecię, które noszę w mym łonie”; „A ja sama, bojaźń mię ogarnęła na myśl, że mogę zasłabnąć bez żadnej pomocy", itd. ${ }^{230}$ Strach przed śmiercią to główne uczucie, które towarzyszyło diarystce w okresie ciąży. Wróblewska porównuje go ze stanami przeżywanymi przez żołnierza na polu bitwy:

Już się zbliża chwila uroczysta, chwila obawy i niepewności; za dni parę mam po raz drugi zostać matką. Nikt jutra pewnym być nie może, śmierć nie pyta i nie oznajmuje, kiedy zawita w nasze progi. Lecz podobne przejście dla każdej kobiety jest tym, czym wojna dla żołnierza, wielu po licznych bitwach wraca zdrowe, radosne, a iluż pada ugodzonych pierwszą kulą. Teraz więcej niż kiedy myśleć powinnam o śmierci ${ }^{231}$.

Dwa lata temu nazad gotowałam się do śmierci, bo dla każdej kobiety przyjście na świat jej dziecięcia może być zapowiednią jej ostatniej chwili ${ }^{232}$.

Takie fobie charakterystyczne były nie tylko dla Wróblewskiej. Nieprzypadkowo większość kobiet przed porodem przygotowywała testament ${ }^{233}$. Rasa Paukštytè,

Zauważyła to również B a ir a ša u sk a it è (Mykolas Juozapas Römeris, s. 230) przeprowadzając badania nad korespondencją Racheli z de Ràés Römerowej (1783-1855), matki sześciorga dzieci.

Zob. Bi ełow a, op. cit., s. 359-360.

Puszkariewa, op. cit., s. 46.

Zob. Bi ełowa, op. cit., s. 348-349.

D2, k. 87v-88v (Wilno, 27 XII 1858).

D2, k. 67v (Wilno, 24 VI 1858), k. 85r (Wilno, 8 X 1858).

D3, k. 31v (Wilno, 11 VI 1860).

D3, k. 89v (Wilno, 14 VI 1862).

Zob. Bołdy rew, op. cit., s. 44. 
badająca codzienność kobiet ze wsi, celnie podsumowała, że ciężarna znajdowała się w stanie przejściowym, w którym jak gdyby stale balansowała między tym a tamtym światem ${ }^{234}$. To samo niedookreślenie, wahanie między „tu” a „tam” widać również w dzienniku - należącej do elity - Wróblewskiej, przygotowującej się do macierzyństwa.

Strach przed śmiercią stanowił jeden z najważniejszych tematów kobiecej literatury egodokumentalnej ${ }^{235}$. To samo można powiedzieć o dziennikach Wróblewskiej, w których autorka odnotowywała utratę i znajomych, i najbliższych - ojca, matki oraz dzieci. Ale ból po śmierci dzieci był wyjątkowy. Oto wpis z dnia śmierci córki Stanisławy, 7 XI 1868 (dziewczynka miała zaledwie cztery lata):

Uleciała do Boga moja Stasiunia, moja malutka ukochana dziecina. Tak mi się pięknie, tak uroczo rozwijał ten ładny kwiateczek, tyle mi pięknych robił nadziei i tak prędko tak nagle usechł. Nie masz jej nigdzie, próżno ją szukają moje oczy, próżno tęskni dusza. Nie ma jej- przyjm, Boże, tą ofiarę ukochanego dziecka ${ }^{236}$.

Emocjonalne przeżywanie utraty dziecka było charakterystyczne dla XIX stulecia. Śmierć potomka coraz częściej postrzegano nie tylko jako Boskie zrządzenie, ale też jako „niemiłe wydarzenie”, które mogły zrekompensować narodziny kolejnego dziecka ${ }^{237}$.

Wróblewska jeszcze bardziej niż śmierć trzech synów i dwóch córek, i to pokazuje jej diarystyczna spuścizna $z$ ostatnich lat prowadzenia dziennika, opłakiwała „strate” żyjących dzieci - Tadeusza Stanisława i, przede wszystkim, Augustyna:

Wieko każdej nowej trumny zamykało ze sobą nie tylko szczęście, lecz szczęścia nadzieję. Jestem dziś rozbitkiem! Jeszcze mi rozhulane morze nie zabrało wszystkich ukochanych. Ale oni z tej strasznej burzy tak wyszli inni, tak tym kataklizmem przenaturzeni, że kocham ich sercem, ale się nie rozumiemy ${ }^{238}$.

Wróblewska, która jeszcze w 1860 r. w dzienniku dla Tadeusza Stanisława pisała: „Cierp lepiej, moje dziecię, cierp dla drugich i za drugich, niżbyś miał w nikczemnej spokojności przedrzemać i zmarnować życie!"239, po 20 latach nie pojmowała ani działalności swoich synów, ani ich nowego światopoglądu. Chociaż próbowała je zrozumieć, sięgała po odpowiednie lektury - wskazuja na to zachowane wśród rękopiśmiennej spuścizny Wróblewskiej konspekty dotyczące teorii socjalizmu

Pa u k šty tè, op. cit., s. 41.

Zob. O. E. G la g o lev a, Dream and Reality of Russian Provincial Young Ladies. 1700-1850. „The Carl Beck Papers in Russian \& East European Studies” 2000, nr 1405, s. 45-46.

D3, k. 137v (Wilno, 7 XI 1868).

Zob. Bołdyrew, op. cit., s. 257-261. Zob. też P. Z Monwid-Białłozorów Kończyna, Dzienniki. 1846-1847, 1851-1853, k. 15v (Łukinia, 15 II 1846, piątek, dzień św. Faustyna i św. Jowity): „Dwa lata temu nazad, jak dziś straciliśmy syna, małego Józia, w Mitawie. Ciężką pierwszą boleścią dotknięte były serca nasze rodzicielskie, nie widzieliśmy, że na rok drugi straszniejsze gotuje się próby, w tejże oto porze Marylka nasza w roku przeszłym ciężko odrę przebywała w nieobecności ojca, a ja z okropną boleścią walczyłam, nie wierząc, żeby mię tak straszny los czekał, żeby to ukochane dziecię w zimnym grobie położyć. Tak! Stało się wszystko, co się stać miało, i nie ma pociechy naszej! Tego widać było potrzeba! Cześć, Panie Bogu!"

D5, k. Ir (1883; nie wskazano dnia ani miesiąca wpisu).

DTW, k. 17v (Wilno, 11 VI 1860). 
- znów obwiniała tylko siebie: „Słusznej dożyłam kary - nie pracowałam nad sobą. Dorosły moje dzieci i wady matki stanęły w całej nagości przed ich oczyma”240. Rodzina Wróblewskich, tak jak Litwa z Polską, była razem, dopóki jej członków łączyła wspólna idea ${ }^{241}$.

W dziennikach Wróblewska utrwaliła jeszcze jedną porażkę - w relacjach z mężem. Ich istotę trafnie oddaje lakoniczne zdanie: „Szczęście Eustachego jest moim szczęściem, celem mych starań i myśli. Miłość jego moją nagrodą i pociechą - lecz ani jednego, ani drugiego zdobyć nie umiałam"242. Ten lejtmotyw wyraźnie zaznacza się w jej całej egodokumentalnej twórczości. Diarystka opowiada historię kobiety kochającej, ale niekochanej. Do ostatnich zdań dziennika przewija się myśl, że to na pierwszy rzut oka idealne małżeństwo (małżonków nie dzieliły społeczne ani finansowe różnice, ani też różnica wieku) nie było takie, jeśli wziąć pod uwagę jej potrzeby i potrzeby Eustachego, może nawet zostało, bez ich wiedzy, zaaranżowane przez otoczenie. Nie należy odrzucać również praktycznego aspektu zawarcia tego związku - niewykluczone, iż stanowił on jeden $z$ argumentów dla Wróblewskiego, który jeszcze do końca nie odbył kary, uzasadniających jego pozostawanie w Wilnie, zwłaszcza po niespodziewanej śmierci pierwszej żony. Być może, stąd wynikały pośpiech i cisza spowijająca przedślubne kontakty. Tak samo umotywowane wydaje się także inne wyjaśnienie: rzeczywistość nie odpowiadała wyobrażeniu, jakie o małżeństwie - najistotniejszym wydarzeniu w życiu każdej kobiety w XIX w. - miała Wróblewska, która opierała się w tym względzie na literaturze pięknej. Na podstawie egodokumentów kobiet i mężczyzn udowodniono już, że ten brak harmonii między złudzeniami a rzeczywistością był najważniejszą przyczyną niepowodzeń małżeńskich już pod koniec w. XVIII i w XIX stuleciu ${ }^{243}$.

Wróblewska obok męża czuła się jak „,bardzo zwyczajna, prozaiczna istota”244. To poczucie mogła wzmacniać również bohaterska przeszłość Eustachego, jego towarzyskość, wreszcie także zawód, który sama - będąc córką lekarza - niezwykle ceniła: ,jego powołanie jest piękne, pożyteczne i pełne poświęcenia”245. Dlatego głównym celem swojego życia uczyniła bycie idealną żoną:

Dzięki Niebom już wyrobiłam w sobie tyle mocy ducha, że nie tak tęsknię, gdy nie ma Eustachego. Żona lekarza powinna się z tym oswoić. Mą̇̇ jej służy cierpiącej ludzkości - a iluż cierpi! Chwile więc jego w domu są policzone. Życie jego, jego praca jest pełna pożytku dla bliźnich. Trzeba też i mnie wedle sił i zdolności moich dobrze użytkować $\mathrm{z}$ czasu, którego mam pod dostatkiem²46.

Czyż spełniam położone we mnie nadzieje, czyż jestem ozdobą, pociechą życia mojego Eustachego?247

Mąż mnie nie potrzebuje, nie tęskni za mną, on stworzony do życia publicznego i na tym polu może być użytecznym, moim więc zadaniem, na nieszczęście dotąd nie pojętym przeze mnie, nie odciagać go od tego, ale owszem, starać się, by on był w swych działaniach najswobodniejszy i by nigdy, gdy mu

D5, k. 4r (Wilno, 31 VIII [1883]).

Zob. D5, k. 52r (Wilno, brak daty; kartka wklejona do zeszytu).

D2, k. 70v (Wilno, 18 VII 1858).

Więcej na ten temat zob. Gla goleva, op. cit., s. 1-87.

D2, k. 53r (Wilno, 13 IV 1858).

D3, k. 77v (Wilno, 14 I 1862).

D2, k. 41v (Wilno, 23 II 1858).

D2, k. 55v (Wilno, 27 IV 1858). 
chęć weźmie zajrzeć, przyłączyć się do kółka rodzinnego, nie znalazł nic, co by go rozdrażnić lub zachmurzyć mogło ${ }^{248}$.

Taka ofiara kobiety, a właściwie ciagła troska o komfort męża, była zgodna z ówczesnym postrzeganiem roli dobrej żony ${ }^{249}$. W każdym razie Wróblewska pozostawiła badaczom życia codziennego, zwłaszcza historii emocjonalności, ponad 50 wpisów, które można oznaczyć jednym słowem: „Eustachy”. Lecz tematyka miłosna, w odróżnieniu od dziennika Gabrieli Mohl-Basanavičienė, w jej diariuszach wcale nie jest najważniejsza - to tylko jeden $z$ wielu tematów.

\section{Dziennik jako świadectwo idei emancypacyjnych i powinności kobiety}

Dzienniki Emilii Wróblewskiej są świadectwem tradycyjnego rozumienia roli kobiety w rodzinie i społeczeństwie, formułowanej zarówno w literaturze specjalistycznej, przeznaczonej dla kobiet, jak i w publicystyce oraz literaturze pięknej (w tej ostatniej przede wszystkim) XIX stulecia. Badacze nazywają tę rolę na wskroś konserwatywna, podbudowaną tradycyjnym, katolickim światopoglądem, którego zwyczajne przesłanie wyraża się w zdaniu: „świat dla mężczyzn, a Bóg i rodzina - dla kobiet”250. Innymi słowy, kobieta przynależy do przestrzeni prywatnej, mężczyzna zaś - do publicznej. Lecz kobieta w tym kraju nosiła jeszcze jedno brzemię: nie tylko musiała być dobrą matką, gospodynią i opiekunką ogniska domowego, ale też pełniła inną, nie mniej ważną funkcję - strzegła tradycyjnych wartości narodowych, religijnych i moralnych. Czyli zaszczepiała cnotę i patriotyzm w swojej rodzinie, a dzięki temu - także w społeczeństwie ${ }^{251}$. Stąd wynikał również obowiązek stałego samodoskonalenia się w „kobiecej profesji”. Wspominałam, że Wróblewska ten wymóg spełniała (albo przynajmniej dążyła do jego spełnienia) bardziej niż gorliwie. Inaczej mówiąc, to, co kobiecie tylko sugerowano, co jedynie jej radzono tylko teoretycznie, Wróblewska wcielała w życie. Oto kilka zdań z jej dziennika:

O, ja chcę być kobietą chrześcjanką, kobietą czynu - nie sławną i głośną, ale prawdziwą kapłanką domowego ogniska, które rozżarzone swym ciepłem i innych ogrzać potrafi ${ }^{252}$.

Większą część dnia jestem zupełnie samotną. W tych to chwilach oddalenia od świata i ludzi powinnam się uczyć, jak mam się okazać w zestosunkowaniu z nimi prawdziwą chrześcijanką, dobrą

D3, k. 95v (Wilno, 14 XI 1862).

Więcej na ten temat zob. M. Stawia k-O s o sińs ka, Ponętna, uległa, akuratna... Ideał i wizerunek kobiety polskiej pierwszej połowy XIX wieku ( $w$ świetle ówczesnych poradników). Kraków 2010, s. 203-232.

T. B a ir a ša uska it è, Moteris šeimoje ir visuomenejje. W: T. B a i r a š u s k a it è, Z. Medišauskienè, R. Miknys, Devynioliktas amžius: visuomené ir valdžia. Vilnius 2011, s. 462: „pasaulis vyrams, o Dievas ir šeima-moterims”.

Zob. np. Z. M ediš a u ski en è: Moters idealas Lietuvos konservatoriu akimis (XIX a. vidurys). W zb.: Feminizmas, visuomené, kultūra. Vilnius 2001, s. 118-127; Namu angelas sargas: moters vieta Lietuvos visuomenejje XIX a. pirmojoje puséje. „Klèja” 2003, nr 8. Na stronie: www.moterys. 1t/assets/leidiniai/index806b.html?show_content_id=632 (dostęp: 2 IX 2015). - J. Mikny tè, Moters socialinio vaidmens monstravimas viešajame diskurse XIX a. vidurio - XX a. pradžios Lietuvoje. (Rozprawa doktorska). Kaunas 2009.

D2, k. 23v (Wilno, 14 XII 1857). 
Polką i kobietą serca. Trzeba czuwać nad sobą - nic sobie nie wybaczać, bo inaczej nie będę wiernie spełniać powołania i posłannictwa swego, które głównie zależy wprawdzie na obowiązkach dobrej żony, pani i gospodyni ${ }^{253}$.

Na Matkę Polkę, Matkę Chrześcijankę dziś obrócone są oczy, na niej leży nadzieja lepszej przyszłości dla kraju, bo w jej ręku utworzenie dobrych synów i córek ojczyzny. Ale jakże świętą i zacną powinna być ta polska matrona, jak wszystkie chwile jej życia pełne. Ona, choć się zajmuje drobiazgowymi nawet szczegółami domu, ale zawsze myśli jej czymś wyższym, ważniejszym zajęte, ona nigdy nie zapomina Wielkiego i Świętego posłannictwa swego, ona nigdy nie utonie w kłopocikach i marnostkach codziennego życia. Przechodzi przez nie, bo musi, ale ani na chwilę się nie zatrzymuje, bo cel jej życia wyższy, on ją podnosi, on jej osładza i trudy, i cierpienia, bo warto jest i mozolić się, i cierpieć dla Boga, dla Kraju, dla ludzkości ${ }^{254}$.

O jedną Cię, Boże, łaskę proszę: naucz mnie, jak córki moje na dobre Żony i Matki wychować, a syna na prawego człowieka pojmującego swoje stanowisko, publiczne i rodzinne ${ }^{255}$.

Najważniejsza myśl wyrażona w tych postulatach (które tak naprawdę nie zostały stworzone przez samą diarystkę - „pożyczyła” je ona z ówczesnej literatury) była bardzo prosta: kobieta nie mogła zapominać, że w hierarchii społecznej stała niżej niż mężczyzna, a w najlepszym wypadku była tylko jego przyjaciółką, pomocnica. Wspominałam, że Wróblewska dążyła przede wszystkim do roli „towarzyszki życia”. Kobietę niezależną, równą mężczyźnie w życiu publicznym, diarystka postrzegała jako odrażająca, przynajmniej we wczesnym okresie swego życia (a te etapy życia łatwo ustalić dzięki zachowanym dziennikom). Na początku $1851 \mathrm{r}$. Wróblewska (miała wówczas 21 lat) uważała nie tylko za fantazję, lecz także za anomalię dążenie kobiet do równouprawnienia albo pozbycia się swego „cichego zawodu":

Słowem, nie chcę być [taką] kobietą. Kobieta! To imię słodkie, zawierające w sobie całą moc czułości, słodyczy, miłości, poświęcenia, cichych i nieznanych cnót. To imię za małym, za niskim jest dla teraźniejszej postępowej damy - ona nie chce być kobietą, bo duch czasu pędzi ją do innej sfery. Ona chce być mężczyzną - dumna, jeśli choć w czymkolwiek go naśladować potrafiła; męczy się, poci, aby stać się, czymże, oto pajacem dla patrzących na nią widzów. A gdy się z tłumu odezwie szyderskie brawo, twarz się jej promieni - na szczycie jest szczęścia, bo wszak już nie jest kobietą, tak, nie jest nią, ale jest potworem, jest wyrodkiem przyrodzenia. I toż jest chlubą, i toż jest chwałą, wynikłością postępu teraźniejszego wieku! ${ }^{256}$

Ogólne przekonania na temat roli kobiet Wróblewska zachowa, ale $z$ biegiem lat i pod wpływem zmian na świecie częściej będą pojawiać się u niej oznaki kompromisu. Zmieniły się nie tylko jej poglądy na kobietę, zmieniły się też same kobiety - w coraz mniejszym stopniu zadowalała je wąska przestrzeń domowa ${ }^{257}$. Pod tym względem za najbardziej charakterystyczny i autentyczny należy uznać wpis, który nie przedstawia powieściowej bohaterki ( $\mathrm{z}$ takich postaci słynęły dzieła Ko-

D2, k. 16r (Wilno, 26 XI 1857).

D3, k. 93v-94r (Wilno, 28 X 1862).

D3, k. 103v (Wilno, 16 VII 1864).

D1, k. 13r-13v (Wilno, 12 I 1851).

Zob. Mano tévyné - prie jo širdies, s. 111 (Praga, 8 III 1884, sobota): „Jak długo miała pod ręką garnek, igłę do szycia i łyżkę do mieszania, była szczęśliwa. Powinna była urodzić się kilka stuleci wcześniej, kiedy kobiety były skazane na ograniczoną sferę działania przy zwierzętach domowych i kądzieli”. 
rzeniewskiego, ulubionego autora Wróblewskiej), ale goszczącą w Wilnie, może i na stałe tam mieszkająca, emancypantkę - bratową przyjaciółki diarystki, Marię F.:

Oryginalna kobieta - wszystkie jej upodobania, zdolności, zatrudnienia są zupełnie niekobiece. Jest snycerka, stolarka, oddaje się chemii, fizyce, żyje rozumem, szuka wszędzie poezji, uroku, wdzięku. Chciałabym ją bliżej poznać, by zobaczyć, czy umie to wszystko pogodzić z obowiazkami dobrej matki, żony, gospodyni, słowem: czy umie też być kobieta. Jakkolwiek jest ona ekscentryczna, podobała mi się jednak ${ }^{258}$.

Być może, najważniejsze są ostatnie słowa: ekscentryczka „podobała mi się jednak". I tu warto dodać, że diarystka czytała nie tylko Klementynę z Tańskich Hoffmanową (1798-1845), nie tylko Ewę $z$ Wendorffów Felińską (1793-1859), Józefinę Osipowską (?-1853), lecz także dzieła Narcyzy Żmichowskiej (1819-1876), którą uznaje się za jedną z prekursorek feminizmu ${ }^{259}$. Coraz łagodniejsze stawały się poglądy Wróblewskiej na edukację kobiet, co szczególnie wyraźnie zaznacza się w dzienniku pisanym dla córki Marii. Wróblewska nie mogła nie widzieć jej zapału do nauki, pracy intelektualnej, zamiłowania do sztuki, dlatego szukała sposobu, by pogodzić w niej „męskie” i „kobiece” podstawy: „Taką będzie moja Maryjka - gospodarka, ręczna praca będą u niej iść w parze $z$ wykształceniem jej główki i serca" ${ }^{260}$. Ta harmonia pomiędzy rozsądkiem, wykształceniem a kobiecością stanowi oczywistą aspirację Wróblewskiej, w tym kierunku projektowała również życie córki:

A praca ręczna koniecznym obowiazkiem. Jeśli nie masz do tego upodobania, to się łam, naginaj - to dla kobiety koniecznie potrzebne, a Ty, która wielkie i szerokie masz plany przed sobą, wiedz, że te piękne zamki dziś nadpowietrzne, bo rzeczywiste, zamienić się tylko wtedy mogá, jeśli je będziesz budować na podstawie głębokiej religijności i na podstawie cnót kobiecych. Wolno jest kobiecie sięgać po wyższe światło, po prawo do samoistnej pracy na nieuprawianym dotąd przez nią polu. Pobłogosławi Bóg i uszanują ludzie, jeśli kobieta, idąc tą drogą, nie przestanie być kobietą, której zadaniem czuwać nad wnętrzem swego domu, nad ładem i porządkiem, której wdziękiem, siłą i urokiem - skromność, słodycz, miłość dla wszystkich ${ }^{261}$.

Wiedziała, że zmieniający się świat oczekiwał od płci pięknej coraz większej aktywności i „męskiej” energii. Właśnie taki ideał kobiety stworzył Tadeusz Stanisław. Ale chociaż Wróblewska zgadzała się, że syn ma podstawy, by tak myśleć, to nie aprobowała podobnego obrazu, traktując go nawet jako zarzut wobec samej siebie:

Nie sympatyzuję z twoim pojęciem kobiety. Muszę przyznać, że pogląd twój jest słuszny i sprawiedliwy - niemniej jednak bolesnym jest dla mnie. Oby Ci Nieba dały przynajmniej żonę, która by odpowiedziała twemu ideałowi. Oby miała obok cnót kobiecie właściwych męską energię i w sobie, której brak było przez całe życie Twojej biednej Matce ${ }^{262}$.

Dzięki prowadzeniu dziennika, zwłaszcza poprzez diarystyczną „rozmowę” z córką, rozwiązywała własne problemy. Sama także nie była stworzona tylko do

D3, k. 13r (Wilno, 8 III 1860).

259 D1, k. 14v (Wilno, 13 I 1851), k. 15v (Wilno, 20 I 1851), k. 62r (Wilno, 6 II 1853, piątek), k. 83v (Wilno, 20 XI 1854), k. 89r (Połaga, 17 VIII 1855).

260 DMW, k. 24v (Wilno, 22 X 1869).

261 DMW, k. 43r-43v (Wilno, [12 VI] 1872).

262 DTW, k. 100v (Wilno, 1886; nie wskazano dnia ani miesiąca wpisu). 
życia rodzinnego. Dziś można już odważnie powiedzieć - miała powołanie do nauki i książek:

Tak, lubię pracę, ale tylko nad książką, a czym innym zupełnie zająć się nie umiem i jestem do niczego - w całym znaczeniu tego wyrazu ${ }^{263}$.

Książka była mi zajęciem, rozrywką, przyjaciółką, towarzystwem, wszystkim, wszystkim na świecie ${ }^{264}$.

Ja tak lubię namiętnie naukę 265 .

Miała powołanie również do pisania. Pomimo że była dla siebie pod tym względem bardzo surowa („Do pióra nie mam zdolności”266), nie ograniczała się do prowadzenia dzienników. Dużą część twórczej spuścizny Wróblewskiej stanowią konspekty przeczytanych książek, ale przetrwały także jej wiersze, przekłady. Streszczać przeczytane książki lubiła i widziała w tym zajęciu dużą korzyść. W jednym z zeszytów, w których umieszczała streszczenia, zanotowała 15 XI 1871: „Piszę to z myśla o mojej córce, chcąc ją zachęcić, by sama też, gdy podrośnie, każde przeczytane dzieło streściła sobie, bo wtedy dopiero prawdziwą jej przyniesie korzyść" 267 . Nieprzypadkowo do naszych dni dotrwało 10 zeszytów Wróblewskiej $\mathrm{z}$ opisami przeczytanych ksiazżek, $\mathrm{z}$ których każdy stanowi przedmiot godny odrębnej analizy - pokazuje nie tylko lektury diarystki, lecz także kierunek jej myślenia. W spuściźnie tej znajdują się również notatki świadczące o aktualności tzw. tematyki kobiecej. Oprócz wspomnianych już autorek, które rozpatrywały te zagadnienia, odnajdujemy w konspektach Wróblewskiej ekcerpty z utworów ówczesnych pisarek: Marii z Trębickich Faleńskiej (1821-1896) i Pauliny z Lauczów Wilkońskiej $(1815-1875)^{268}$.

Oryginalna twórczość diarystki zajmuje najmniej miejsca w jej zachowanej spuściźnie. Do naszych dni dotrwało kilka wierszy, z których największe wrażenie robi jeden - dedykowany Marii, napisany już po jej śmierci ${ }^{269}$. Jako priorytetowe Wróblewska traktowała tłumaczenia. Pozycje do przekładów wybierała skrupulatnie, książki czasami nawet zamawiała $z$ zagranicy ${ }^{270}$. Tłumaczenie uważała zresztą za korzystne zastępstwo prac ręcznych. W roku 1858 pisała:

Od dawna przemyśliwałam, by wynaleźć jakieś pożyteczne zajęcie z korzyścią dla siebie lub drugich. Do pracy ręcznej nie jestem wdrożoną i na tej niwie nieprędko bym coś zebrała. Przyszło mi na myśl, że mogłabym wziąć jakieś dzieło, starannie je przetłumaczyć i podać do druku²71.

W odróżnieniu od robótek ręcznych do pracy twórczej nie czuła odrazy, tylko

D1, k. 69r (Połąa, 22 VII 1853).

D2, k. 5r (wpis wprowadzający; Wilno, 1856).

D2, k. 8v (Wilno, 22 V 1856).

D5, k. 7r (Wilno, 9 XI 1883).

E. z Beniowskich Wróblews ka, Treść moich czytań. 1871. BWLAN. Rkps 9-902, k. 1r.

E. Z Beniowskich Wróblewska, Konspekty utworów literackich. 1852-1861. Jw., rkps 9-997, k. 7v-8v (w językach polskim i francuskim).

Zob. Wróblews ki, Sztambuch, k. 45r (wiersz E. z Beniowskich Wróblewskiej dedykowany córce Marii).

D3, k. 7v-8r (Wilno, 4 II 1860).

D2, k. 80v (Wilno, 24 IX 1858). 
duże upodobanie ${ }^{272}$. Wróblewska miała wszystkie cechy literatki i, odważyłabym się stwierdzić, nawet emancypantki. Lecz - na co wskazują wyraźnie jej dzienniki - skłonność do emancypacji cały czas u siebie zwalczała, w zamian za to wybierała „kobieca profesję”. „Czyż moje "ja" ma być celem mojego życia!” - oświadczyła diarystka w 1860 roku $^{273}$. W takich dziennikowych wtrętach Wróblewska zachowuje się jak staroświecka kobieta. $Z$ drugiej strony, chociaż „pracowała dla rodziny”, zdradzała bardzo wyraźne cechy samotnika - wśród ludzi czuła się, jak gdyby do nich nie przystawała, nie pasowała: „bo ja jakoś nigdy [nie] umiem harmonijować ze światem - jak dziki kwiatek w bukiecie róż, tulipanów, goździków zda się chować" ${ }^{274}$. Żyła dziwnym, zamkniętym życiem - na tyle zamkniętym, na ile pozwalały na to obowiązki żony i matki, niezbędnym, by móc pisać, tworzyć, czytać. Miała talent pisarski - wskazuje na to cytat z jej dziennika, chyba najpiękniejszy:

Nie podoba się jej po świetnym Paryżu biedna nasza Litwa, ze swym czarnym chlebem, nędznymi hotelami, wiśniowymi chłopami. Przelotem widziałam zagraniczne kraje, ale nad wszytkie komforty, bon genre i okrzyczaną tak głośno i szeroko cywilizacją Wschodu wolę biedny mój kraj! Wszystko w nim kocham: i ziemię, i ludzi, i niebo nasze chmurne. I daj mi, Boże, z tymi ludźmi siać i zbierać, z nimi żyć i z nimi umierać $!^{275}$

W zdaniach tych nie jest istotna jedynie tzw. tematyka kobieca - tym razem oburzenie wzbudza we Wróblewskiej dziewczyna wychowana za granica. Wrażenie robi nie tyle motyw patriotyczny, ile styl autorki, sposób mówienia, zbliżający dziennik do literatury pięknej. „Jestem zmęczona, fizycznie złamana, ale to wszystko drobnostka. Byle w duszy była cisza i zadowolenie!" - ten lakoniczny, lecz emocjonalnie sugestywny wpis w dzienniku pochodzi z $1860 \mathrm{roku}^{276}$. Albo jeszcze krótszy, ale wyrażający całe spektrum uczuć wobec syna Tadeusza Stanisława, $\mathrm{z}$ lutego 1886 (to jedno $\mathrm{z}$ ostatnich zdań zanotowanych przez diarystkę $\mathrm{w}$ dzienniku): „Czekam, ufam, kocham”277. Inaczej mówiąc, dziennik Emilii Wróblewskiej dziś można nazwać literaturą o wysokiej wartości - nawet jeśli takiemu wnioskowi sprzeciwiłaby się sama diarystka, nigdy nie pretendująca, by zostać pisarką. Ta niefikcjonalna literatura zbliża nas nie tylko do świata ówczesnej kobiety, lecz także do odmalowanego jej piórem świata mężczyzn. Co więcej - w dzienniku tym te dwa światy spotykają się, istnieją nie oddzielnie, ale jako całość.

\section{Podsumowanie albo biografia uczuć}

„Czyliż życie wnętrzne tak jest trudne?” - retorycznie pyta Wróblewska278. Dzisiaj rzadko ktokolwiek zagląda do jej dzienników, ponieważ dla wielu diariusz kobiecy

Wskazują na to również inne rękopisy jej prac. Zob. E. z Beniowskich Wróblewska, Okruchy Złote. Wiazanka malutkich rad dla uświęcenia i uszczęśliwienia życia. 1868-1873. Cz.1-2. BWLAN. Rkps 9-929, k. 1r-155v.

D3, k. 15r-15v (Wilno, 11 III 1860).

D1, k. 17r (Wilno, 31 I 1851).

D2, k. 42r (Wilno, 23 II 1858).

D3, k. 17r (Wilno, 17 III 1860).

DTW, k. 73r (Wilno, 15 II 1869).

D3, k. 92r (Wilno, wrzesień 1862). 
stanowi nadal marginalne źródło historyczne, dyletancką, a nawet epigońską literature „do szuflady”. Ale słyszymy już całkowicie przeciwne głosy, twierdzące, że te „milczące teksty” są również autentycznym, spontanicznym, niezmyślonym źródłem. Wielu sądzi, że ówczesna kobieta była w stanie przekazać na „poziomie uczuć” jeszcze głębiej i wyraźniej od tzw. realiów ślady historii; że kobieta „napiętą emocjonalnością" intensywniej niż mężczyzna wchłania w siebie i przekazuje osobliwości tego $\mathrm{czasu}^{279}$. Dlatego nieprzypadkowo Jurij Łotman kobietę nazwał wprost jednym $z$ najczulszych barometrów życia społecznego ${ }^{280}$. Dzisiaj, kiedy nie tylko XIX-wieczna diarystyka męska i kobieca uznawana jest już za źródło historyczne i tekst literacki, kiedy twórczość egodokumentalna kobiet dla wielu staje się odkrytym na nowo polem badawczym, przychodzi również czas na odczytywanie i analizowanie dzienników Wróblewskiej. Mówi się, że obecnie dzięki takim tekstom zupełnie nieznane kobiety sa „uhistoryczniane”. W przypadku Wróblewskiej sąd ten potwierdza się tylko częściowo - została ona „uhistoryczniona”, ponieważ była matką Tadeusza Stanisława i Augustyna Wróblewskich. To jednak za mało. Ta kobieta ma również swoją biografię. Co więcej - nawet najmniejsze zetknięcie się z dziennikami Emilii Wróblewskiej otwiera niespodziewane perspektywy. Przecież nie każdy pozostawia po sobie biografię swoich uczuć.

\title{
Z litewskiego przełożyła Emilia Kolinko
}

\author{
Abstract
}

REDA GRIŠKAITĖ Lithuanian Institute of History, Vilnius

\section{DIARIES OF EMILIA WRÓBLEWSKA OF THE HOUSE OF BENIOWSCY}

Emilia Wróblewska is little known in Polish and Lithuanian culture and mainly remembered as the mother of Tadeusz Stanisław (a famous political activist) and of Augustyn (chemist, social activist and anarchist). The Library of Lithuanian Academy of Sciences in Vilnius treasures in its collection a rich archive of Emilia and Eustachy Wróblewscy, including Wróblewska's letters, her diaries, translations and poems. The sources shed a totally new light on the figure: she is seen as an amateur woman of letters, unhappy wife, a devoted mother and a woman who on the one hand tried to realize her duties, and, on the other hand, as the one who wanted to cross the boundaries of the role she was given by the $19^{\text {th }}$ conventions. The article presents the diarst's detailed bibliographical data and a literary analysis of her rich handwritten creativity.

Zob. K. Ki elli, Prawo na emocyi, prawilnyje emocyi. Uprawlenije czuwstwami w Rossii posle epochi Proswieszczenija. W zb.: Rossijskaja impierija czuwstw. Podchody k kulturnoj istorii emocyi. Ried. Ja. Płampier, Sz. Sza chad at, M. Eli. Moskwa 2010, s. 54-55. O badaniach poświęconych historii uczuć i ich wyrażania zob. też M. Fige a c, Radości $i$ smutki $w$ piśmiennictwie prywatnym wieku oświecenia. „Wiadomości Historyczne” 2007, nr 6. 